\title{
Link between Social Distancing, Cognitive Dissonance, and Social Networking Site Usage Intensity: A Country-Level Study during the COVID-19 Outbreak
}

\author{
Tanusree Chakraborty \\ Rajalakshmi School of Business, Chennai, India \\ Email : tanusree@rsb.edu.in
}

\author{
Anup Kumar \\ Institute of Management Technology (IMT) Nagpur, India \\ Email: anunewin@gmail.com \\ Parijat Upadhyay \\ Institute of Management Technology (IMT) Nagpur, India \\ Email: parijat.upadhyay@gmail.com \\ Yogesh K Dwivedi \\ School of Management, Swansea University Bay Campus, \\ Skewen, Swansea SA1 8EN, UK \\ Email: ykdwivedi@gmail.com
}

\begin{abstract}
Purpose

Social distancing is an important strategy to control the spread of the COVID-19 pandemic, so it is imperative to understand the behavioral impact of social distancing on individuals. This research studied social distancing from a cognitive appraisal of voluntary social distancing compliance (CAVSD) point of view and a non-medical perspective, specifically the psychological impact (PI) of social distancing on the usage intensity of social networking sites (SNS) during the COVID-19 outbreak in India.
\end{abstract}

\section{Methodology}

The study was conducted on 477 SNS users as a full sample and groups based on age, sex, and work status. The model was empirically investigated using structural equation modeling.

\section{Findings}

CAVSD was negatively associated with PI although not a significant predictor, while CAVSD and PI were significant predictors of SNS usage intensity; moreover, SNS usage intensity differed between groups of people.

\section{Practical implications}

These findings are significant for organizations, corporations and educational institutions in both the public and private sectors. There is a need to identify subsections of individuals in 
need of social support and relief from isolation and loneliness. Individuals are relying on social media to handle social distancing and the pandemic and this shows up in an increase in social networking activity.

\section{Novelty}

This study posits that networking on social media platforms is a virtual manifestation of a basic need for socialization. This study is the first to examine the effect of social networking during a pandemic.

\section{Keywords}

Social network intensity, COVID-19, social distancing, psychological impact, cognitive appraisal.

\section{Paper type}

Research paper

\section{Introduction}

Information and communication technology (ICT) have transformed the ways in which individuals connect with one another. ICT and computer-mediated communications now dominate global communication. When people have less opportunity to communicate face-toface, dependence on technology-based interaction is heightened (Barnes, 2020; Cocosila and Turel, 2019; De'et al., 2020; Dwivedi et al., 2020; Menon, 2011; Nabity-Grover et al., 2020). In January 2020, an outbreak of the highly contagious coronavirus disease (COVID-19) spread across the globe, compelling the World Health Organization (WHO) to declare it a pandemic. The Indian government announced several preventive measures, including social distancing, to minimize the spread of COVID-19. This was followed by a lengthy lockdown or home quarantine. Many people, excluding those in essential services, had to work from home and students were required to study online.

Social distancing required schools to close (Qualls et al., 2017) and measures to avoiding person-to-person spread of the disease were introduced (Wilder-Smith and Freedman, 2020). From a health perspective, social distancing helped to reduce pressure on health services and inhibited the spread of COVID-19 (Koo et al., 2020). Voluntary social distancing was impacted by the membership and the extent of media consumption (Andersen, 2020).

People understood the health threat posed by COVID-19 but at the same time found it challenging to maintain social distance. Social distancing created an attitude-behavior discrepancy in individuals and this generated a form of cognitive dissonance. The term cognitive dissonance was originally coined by Festinger (1957) and refers to a perceived inconsistency in the perceptions an individual has about an object or phenomenon. The individual consequently seeks to implement a strategy to minimize the discomfort that arises from this inconsistency. As a natural response to dissolving the cognitive dissonance during the COVID-19 pandemic, individuals either adopted extreme caution, embraced social distancing (voluntary or compliance), or they engaged in social distancing involuntarily (forced social distancing). The higher the extent of the dissonance, the higher the need to lessen it. In the case of social distancing, as a coping mechanism to combat isolation stress, 
individuals responded to their cognitive dissonance by increasing virtual networking to negate feelings of isolation. Therefore, it becomes important to study if social network sites (SNS) usage during periods of enforced/voluntary isolation, as in the case of a pandemic, changes. Furthermore, it is also important to note that during a pandemic, long-term social needs are not just personal, but also extend to corporate and academic lives.

Social networking is a common phenomenon in society. Social networks (e.g., Twitter, Facebook, and Instagram) have disrupted the way people network, converse, and engage in their day-to-day life. Media capabilities and the media richness of devices, such as smartphone-based SNS, now determine social relations (Choi, 2019). Researchers have found other motivating factors such as individual factors, organizational factors and interpersonal factors also lead to increased SNS use (Lee, 2020). The social networking platforms have given individuals a new way to "hang out" in society. Some motivation and technical factors maintain social media use and addiction among people (Cao et al., 2020). These platforms are not an unalloyed blessing as they have both good and bad effects (Arora et al., 2019; Dwivedi et al., 2018). Social distancing is like a nudge that is beneficial to society at large. Nudges are applied for the well-being of society (Cioffi et al., 2015; Graham et al., 2017; Kallbekken and Sælen, 2013; Momsen and Stoerk, 2014; Vallgårda, 2012). At the end of 2019, the number of social media users in India was estimated to grow to 351.4 million. During a pandemic, the number of people who become media dependent and engage in SNS usage is high and represents a significant proportion of a country's population.

Though every individual in the country was expected to engage in social distancing, the perception of social distancing, cognitive dissonance, psychological impact of social distancing, and coping by social networking might not be taken equally seriously by different groups of people: sex, age, and during social distancing, people who work from home (WFH), those who stay at home but do not work from home (NWFH), and the cohort of students learning online (SLO).

One report (Hoof, 2020) opined that lockdown would lead to a secondary epidemic of burnout and psychological stress coupled with absenteeism from work in the second half of 2020. As most people were not able to engage publicly, there was an increase in the usage of the Internet and social media. People turn to online platforms for all kinds of purposes: entertainment, conversation, shopping, and networking. The COVID-19 outbreak also saw an increase in incidences of anxiety, insomnia, fear of financial crises, stress, and sleep disorders (O'Dair and Fazel, 2020). Behavior on social media platforms differed between older groups of people and youngsters (Zaphiris and Sarwar, 2006; Lipsman 2006; Wright, 2000), between men and women (Herring, 1993; Verhaagen, 2005, Thompson and Lougheed, 2012), and in some cases, because of individual differences. Against such a backdrop, it is crucial to study the impact of imposing restrictions on people's movement and increased SNS usage among different groups of people. Very few studies have looked at the psychological toll of social distancing in the general population, let alone specific groups of people.

This pandemic has created a new "normal" and with it the implications and motivational aspects of SNS use. This study attempted to understand its implications from both an academic and an industry perspective. This is doubly important for a developing economy like India, where SNS usage is widely prevalent. This study covered the period of the COVID-19 outbreak and enforced social distancing and lockdown, and endeavored to explore the relationship between CAVSD and PI on individuals from the perspective of voluntary/forced compliance; examined the relationship between PI and SNS usage intensity among social network users; and finally, probed the relationship between CAVSD and SNS 
usage intensity in groups categorized by sex, age and work status by exploring the characteristics of these groups and how they connected to others using SNS.

Therefore, the study investigated the following research questions:

1. How does CAVSD affect the various groups categorized by sex, age, and work status?

2. How does PI affect SNS usage intensity in the groups categorized by sex, age, and work status?

3. How does CAVSD affect SNS usage intensity in the groups categorized by sex, age, and work status?

The data used in this study were collected from India only. While this may be viewed as a limitation of the study, this was also the first attempt to study the effects of a pandemic, specifically social distancing, on psychological health and social networking behavior.

The manuscript is structured in the following manner: Section 2 provides a brief review of the related work, Section 3 focuses on the theoretical background and hypothesis development, Section 4 presents the research methodology and data collection, Section 5 reports on the findings and the results of the study, Section 6 contains the discussion about theoretical and practical implications of the research, while Section 7 reports on the conclusion, limitations, and future research directions.

\section{Review of literature}

\subsection{Social networking}

Social networking brings people closer together and people across the globe spend a lot of their time on social networks (Roberts et al., 2005; Nielsen, 2006; Ellison et al., 2007), moreover, social media can help with self-disclosure, can be instrumental to the development of self-concept and identity (Matsuba, 2006), and is at the epicenter of human communication (Boyd and Ellison, 2007). Social networking has been adopted by people for a variety of reasons (Wilson et al., 2012). Research suggests that there is a sex difference in social media usage (Lai et al., 2019). SNS is used more frequently by women (Kimbrough et al., 2013); men and women are differently motivated to use the internet (Fallows, 2005). Facebook is used equally by both men and women (Hargittai, 2008), although Taylor (2009) found that more women use Facebook than men. Contrarily, Benson et al. (2019) proposed there was no difference in SNS use between men and women. Studies have found that older adults are more inclined to use SNS to re-establish lost connections (Pew Research, 2010), although Nielsen (2009) asserted that older people engage quite well in SNS use. One study found that adults over the age of 50 years made use of social networking to strengthen their social connections (Hogeboom et al., 2010), while another study found that age had no impact on internet behavior (Hawi and Samaha, 2019). All these studies lead to an inconclusive result.

When people work from home during social distancing and a lockdown, increased bonding has been reported using SNS with team mates (Tolette, 2020). Related to work-fromhomework habits, one study found that WFH habits did not match regular office schedules and people kept flexible work hours (Sproull et al., 1984). While working from home, people have an opportunity to engage in social networking at their own convenience because their work schedules are more flexible (Chakraborty, 2020). However, there have been no studies that explore psychological dimensions related to $\mathrm{WFH}$, and more so during a crisis situation. Further, nothing has been reported about SNS behavior of any of the groups discussed above, 
viz., age, sex, and work status, during a situation where people are required to maintain social distancing, voluntarily or involuntarily, during epidemics and pandemics, or during natural disasters such as cyclones, earthquakes, and other natural disasters.

\subsection{Psychological factors and social networking}

Research suggests there is a connection between social networking and psychological correlates, with specific reference to computer-mediated communication. It was indicated that in general, internet usage impacts social relationships and engagement in physical interactions with others (Sideri et al., 2019; Whelan et al., 2020). This study asserts that the more an individual becomes attached to internet-based communication, the lower his sense of well-being and the poorer his relationship with family members or friends and that this in turn will impact the individual's feelings of depression and loneliness (Kraut et al., 1998; Putnam, 1995). Studies have shown the negative impact of social exclusion, denial, and ostracism (De Wall and Baumeister, 2006). Social networking provides a substitute for physical proximity and helps people to stay connected in a virtual world. When individuals are deprived of social engagement, they have a poorer quality of life and health, both physically and psychologically (Cohen and Wills, 1985; Wellman and Tindall, 1993; Katz and Aspden, 1997). Social networking and psychological factors are correlated. A study by Ponnusamy et al., (2020) found that the well-being of individuals negatively moderated the association between social needs and individuals' addiction to social media platforms like Instagram. In another study, the authors found that WhatsApp and Snapchat increased individuals' information overload, which in turn amplified depressive symptoms that affected their well-being (Matthes et al., 2020). Loneliness has also been found to be linked to social media use and social networking. Individuals' continuous Facebook usage was found to be linked with loneliness; at the same time, the higher the number of friends on Facebook, the less users' loneliness (Phu and Gow, 2019). Individuals also use smartphones as means to escape loneliness (Shen and Wang, 2019) and lonely and neurotic individuals who make greater use of social networking become more stressed. Cabin fever syndrome (Seitz, 2019) is a term used to describe a common reaction pattern in individuals when they are isolated at home or in a building for a certain length of time. In the context of the COVID-19 pandemic, cabin fever syndrome might be experienced by quarantined individuals under stress due to social distancing. Research has found a link between the psychological framework of an individual and social networking.

Table 1 depicts on analysis, that there is a clear gap in literature with respect to the cognitive appraisal of social distancing, the role of cognitive dissonance, the psychological impact felt, and the impact on SNS usage during a crisis situation like a pandemic (Table 1).

Table 1. An overview of prior studies related to this research context

\begin{tabular}{|l|l|l|l|l|}
\hline \multicolumn{1}{|c|}{ Source } & \multicolumn{1}{|c|}{$\begin{array}{c}\text { The focus of the prior } \\
\text { study }\end{array}$} & Critical finding & \multicolumn{1}{|c|}{ Basic theory } & \multicolumn{1}{|c|}{$\begin{array}{c}\text { The variable used } \\
\text { (exogenous/ } \\
\text { intervening/ } \\
\text { dependent) }\end{array}$} \\
\hline $\begin{array}{l}\text { Li } \text { et } \text { al. } \\
(2020) ;\end{array}$ & $\begin{array}{l}\text { Stress in social networks, } \\
\text { Social media diffusion in } \\
\text { Zhou } \text { et } \text { al. } \\
\text { propis situations, and }\end{array}$ & $\begin{array}{l}\text { Use of social } \\
\text { networks to estimate } \\
\text { and track mental } \\
\text { health transition in } \\
\text { adolescents under }\end{array}$ & $\begin{array}{l}\text { These papers } \\
\text { used subjective } \\
\text { self-reporting } \\
\text { and continuous }\end{array}$ & $\begin{array}{l}\text { Peer relationships, } \\
\text { romantic relationships, } \\
\text { family life, self- } \\
\text { cognition, and school }\end{array}$ \\
\hline
\end{tabular}




\begin{tabular}{|c|c|c|c|c|}
\hline $\begin{array}{l}(2020) ; \\
\text { Dou et al. } \\
(2020) ;\end{array}$ & network. & stress. & tracking research & life. \\
\hline $\begin{array}{l}\text { Zhang and } \\
\text { Smith } \\
(2019)\end{array}$ & $\begin{array}{l}\text { Relationship between } \\
\text { bonding and dissonance }\end{array}$ & $\begin{array}{l}\text { Emotional } \\
\text { engagements are } \\
\text { dependent on } \\
\text { emotional } \\
\text { intelligence }\end{array}$ & $\begin{array}{l}\text { This study is } \\
\text { ontologically and } \\
\text { epistemologicall } \\
\text { y based within } \\
\text { critical realism, } \\
\text { which recognizes } \\
\text { that while } \\
\text { epistemologicall } \\
\text { y knowledge is } \\
\text { neither theory } \\
\text { nor value } \\
\text { neutral, there is, } \\
\text { nevertheless, an } \\
\text { ontological } \\
\text { reality } \\
\text { independent of } \\
\text { the } \\
\text { conceptualizatio } \\
\text { n. }\end{array}$ & $\begin{array}{l}\text { Emotional engagement, } \\
\text { social Impact, social } \\
\text { interactions, and } \\
\text { collective effort }\end{array}$ \\
\hline $\begin{array}{l}\text { Shelton et } \\
\text { al.(2019) }\end{array}$ & $\begin{array}{l}\text { Measuring and applying } \\
\text { social network analysis } \\
\text { (SNA) to public health }\end{array}$ & $\begin{array}{l}\text { The most commonly } \\
\text { described measures } \\
\text { were network } \\
\text { density, size, and } \\
\text { degree centrality }\end{array}$ & Literature review & $\begin{array}{l}\text { Social network } \\
\text { intensity, social network } \\
\text { analysis, and } \\
\text { sustainability of health } \\
\text { behavior interventions }\end{array}$ \\
\hline $\begin{array}{l}\text { Li et al. } \\
(2019)\end{array}$ & $\begin{array}{l}\text { Multi-layer local } \\
\text { community detection } \\
\text { model }\end{array}$ & $\begin{array}{l}\text { The model utilizes } \\
\text { node attribute } \\
\text { information and the } \\
\text { similarity strength } \\
\text { information } \\
\text { revealed by social } \\
\text { exchanges to } \\
\text { improve the } \\
\text { accuracy of } \\
\text { community } \\
\text { detection in a social } \\
\text { media network. }\end{array}$ & Network theory & Network Models \\
\hline $\begin{array}{l}\text { Bhimani et } \\
\text { al. (2019) }\end{array}$ & $\begin{array}{l}\text { Social media's potential } \\
\text { for innovation }\end{array}$ & $\begin{array}{l}\text { Social media is seen } \\
\text { as and enabler and a } \\
\text { driver of innovation, } \\
\text { with behavioral and } \\
\text { resource based } \\
\text { perspectives being } \\
\text { the most popular } \\
\text { theoretical lens used } \\
\text { by researchers. }\end{array}$ & $\begin{array}{l}\text { Systematic } \\
\text { literature review }\end{array}$ & $\begin{array}{l}\text { Marketing innovation, } \\
\text { social innovation, } \\
\text { product innovation, } \\
\text { process innovation, } \\
\text { technical innovation, } \\
\text { and service innovation }\end{array}$ \\
\hline $\begin{array}{l}\text { Vaidis and } \\
\text { Bran } \\
(2019)\end{array}$ & $\begin{array}{l}\text { Cognitive dissonance } \\
\text { theory (CDT) }\end{array}$ & $\begin{array}{l}\text { Focus on } \\
\text { operational } \\
\text { distinctions between }\end{array}$ & $\begin{array}{l}\text { Cognitive } \\
\text { dissonance } \\
\text { theory (CDT) }\end{array}$ & Cognitive dissonance \\
\hline
\end{tabular}




\begin{tabular}{|c|c|c|c|c|}
\hline & & $\begin{array}{l}\text { the elements of } \\
\text { CDT: inconsistency, } \\
\text { dissonance (CDS) } \\
\text { and regulation } \\
\text { strategies. }\end{array}$ & & \\
\hline $\begin{array}{l}\text { Carpenter } \\
(2019)\end{array}$ & Cognitive dissonance & $\begin{array}{l}\text { Motivation creates a } \\
\text { set of constraints on } \\
\text { the kinds of beliefs } \\
\text { they are willing to } \\
\text { accept. Beliefs that } \\
\text { are constrained by } \\
\text { their connection to } \\
\text { the individual's self- } \\
\text { concept as a } \\
\text { reasonable and } \\
\text { moral person are } \\
\text { difficult to change } \\
\text { because their } \\
\text { connection to the } \\
\text { self-concept gives } \\
\text { them more weight } \\
\text { such that the } \\
\text { individual will be } \\
\text { motivated to satisfy } \\
\text { those constraints on } \\
\text { their cognitive } \\
\text { network rather than } \\
\text { others. }\end{array}$ & $\begin{array}{l}\text { Cognitive } \\
\text { dissonance, ego- } \\
\text { involvement, and } \\
\text { motivated } \\
\text { reasoning }\end{array}$ & $\begin{array}{l}\text { Cognitive dissonance, } \\
\text { ego-involvement, and } \\
\text { motivated reasoning }\end{array}$ \\
\hline $\begin{array}{l}\text { Jost et al. } \\
(2018)\end{array}$ & $\begin{array}{l}\text { How does social media } \\
\text { facilitate the exchange of } \\
\text { information? Evidence } \\
\text { from studies of protest } \\
\text { movements in the United } \\
\text { States, Spain, Turkey, and } \\
\text { Ukraine using social } \\
\text { media. }\end{array}$ & $\begin{array}{l}\text { Social media } \\
\text { platforms facilitate } \\
\text { the exchange of } \\
\text { information that is } \\
\text { vital to the } \\
\text { coordination of } \\
\text { protest activities, } \\
\text { such as news about } \\
\text { transportation, } \\
\text { turnout, police } \\
\text { presence, violence, } \\
\text { medical services etc. }\end{array}$ & $\begin{array}{l}\text { Content analysis } \\
\text { of tweets from } \\
\text { an Occupy Wall } \\
\text { Street } \\
\text { Demonstration }\end{array}$ & $\begin{array}{l}\text { Social media, } \\
\text { information, motivation, } \\
\text { and social networks }\end{array}$ \\
\hline $\begin{array}{l}\text { Liu and } \\
\text { Wang } \\
(2018)\end{array}$ & $\begin{array}{l}\text { Boundary coordination } \\
\text { and boundary turbulence } \\
\text { can influence individuals' } \\
\text { self-disclosure decisions } \\
\text { on social network sites }\end{array}$ & $\begin{array}{l}\text { Uncertainty } \\
\text { avoidance } \\
\text { moderated the path } \\
\text { from role conflict, } \\
\text { privacy risk, and } \\
\text { privacy control }\end{array}$ & $\begin{array}{l}\text { Communication } \\
\text { privacy } \\
\text { management } \\
(\mathrm{CPM}) \text { theory }\end{array}$ & $\begin{array}{l}\text { Self-disclosure, privacy } \\
\text { control, privacy risk, } \\
\text { and social rewards }\end{array}$ \\
\hline $\begin{array}{l}\text { Leonardi } \\
(2018)\end{array}$ & $\begin{array}{l}\text { This study explores } \\
\text { whether employees who } \\
\text { have access to social } \\
\text { media are more likely than } \\
\text { employees who do not to } \\
\text { develop shared } \\
\text { cognition-similar } \\
\text { perceptions of what and } \\
\text { who coworkers know. }\end{array}$ & $\begin{array}{l}\text { Shared cognition } \\
\text { developed much } \\
\text { more strongly over } \\
\text { six months in the } \\
\text { group that used the } \\
\text { social networking } \\
\text { site than the group } \\
\text { that did not use it. }\end{array}$ & Shared cognition & $\begin{array}{l}\text { Shared experience, } \\
\text { shared cognition, and } \\
\text { social media use, } \\
\text { cognitive knowledge, } \\
\text { treatment condition, } \\
\text { tenure dissimilarity, } \\
\text { hierarchical } \\
\text { dissimilarity, proximity, } \\
\text { common team }\end{array}$ \\
\hline
\end{tabular}




\begin{tabular}{|c|c|c|c|c|}
\hline & & & & $\begin{array}{l}\text { membership, friendship } \\
\text { relationship, advice } \\
\text { relationship }\end{array}$ \\
\hline $\begin{array}{l}\text { Hernández- } \\
\text { Ortega } \\
(2018)\end{array}$ & $\begin{array}{l}\text { Social psychological } \\
\text { distance }\end{array}$ & $\begin{array}{l}\text { Social psychological } \\
\text { distance mediates } \\
\text { the effect of online } \\
\text { consumer reviews } \\
\text { (OCR) on the } \\
\text { receiver's responses. } \\
\text { Less psychological } \\
\text { distance between } \\
\text { strangers improves } \\
\text { the receiver's } \\
\text { responses. }\end{array}$ & $\begin{array}{l}\text { Construal level } \\
\text { theory (CLT) }\end{array}$ & $\begin{array}{l}\text { Social psychological } \\
\text { distance }\end{array}$ \\
\hline $\begin{array}{l}\text { Tsovaltzi } \\
\text { et al. } \\
\text { (2017) }\end{array}$ & $\begin{array}{l}\text { Preparation and } \\
\text { argumentation scripts on } \\
\text { social network sites }\end{array}$ & $\begin{array}{l}\text { Negative effects of } \\
\text { individual } \\
\text { preparation, } \\
\text { ascribed to lack of } \\
\text { knowledge co- } \\
\text { construction and } \\
\text { knowledge } \\
\text { convergence that } \\
\text { point to knowledge } \\
\text { consolidation. }\end{array}$ & $\begin{array}{l}\text { Learning and } \\
\text { instruction }\end{array}$ & $\begin{array}{l}\text { Individual preparation } \\
\text { and argumentation }\end{array}$ \\
\hline $\begin{array}{l}\text { Tsovaltzi } \\
\text { et al. } \\
\text { (2017) }\end{array}$ & $\begin{array}{l}\text { Social network site usage } \\
\text { (discussions) }\end{array}$ & $\begin{array}{l}\text { Group awareness } \\
\text { tools (GATs) and } \\
\text { argumentation script } \\
\text { influence group } \\
\text { processes, but } \\
\text { argumentation script } \\
\text { shows more } \\
\text { substantial } \\
\text { influence. }\end{array}$ & $\begin{array}{l}\text { Socio-cognitive } \\
\text { conflict } \\
\text { awareness }\end{array}$ & $\begin{array}{l}\text { Attitude conflict } \\
\text { awareness, } \\
\text { argumentation scripts } \\
\text { and cognitive guidance }\end{array}$ \\
\hline $\begin{array}{l}\text { Kaplan et } \\
\text { al. }(2016) \text {; } \\
\text { Tokunaga } \\
(2016)\end{array}$ & $\begin{array}{l}\text { Migration intentions of } \\
\text { current and future } \\
\text { knowledge workers }\end{array}$ & $\begin{array}{l}\text { Migration intentions } \\
\text { positively associate } \\
\text { with social networks } \\
\text { in other cities, } \\
\text { subjective norms } \\
\text { that West- is better } \\
\text { than East-Germany, } \\
\text { and that other } \\
\text { regions provide } \\
\text { better life } \\
\text { opportunities; } \\
\text { staying intentions } \\
\text { positively relate to } \\
\text { having origins, close } \\
\text { friends and family } \\
\text { in Saxony }\end{array}$ & $\begin{array}{l}\text { Theory of } \\
\text { Planned behavior }\end{array}$ & $\begin{array}{l}\text { Migration intention, } \\
\text { social networks, } \\
\text { subjective norms, } \\
\text { staying intentions, } \\
\text { structure of the social } \\
\text { networks, socio- } \\
\text { economic } \\
\text { characteristics, travel } \\
\text { habits, and on-line } \\
\text { social networks }\end{array}$ \\
\hline $\begin{array}{l}\text { Marcy } \\
(2015)\end{array}$ & Social innovations & $\begin{array}{l}\text { Leading a radical } \\
\text { social innovation is } \\
\text { no small task and } \\
\text { requires help. }\end{array}$ & $\begin{array}{l}\text { Case study } \\
\text { approach and } \\
\text { drawing from the } \\
\text { historic record }\end{array}$ & $\begin{array}{l}\text { Cognitive attributes, } \\
\text { mental model, social } \\
\text { relationships }\end{array}$ \\
\hline $\begin{array}{l}\text { Han et al. } \\
(2015)\end{array}$ & $\begin{array}{l}\text { Antecedents of social } \\
\text { presence and gratification } \\
\text { of social connection needs }\end{array}$ & $\begin{array}{l}\text { Users are drawn to } \\
\text { SNS to fulfill their } \\
\text { social connection } \\
\text { needs and that the }\end{array}$ & $\begin{array}{l}\text { Usage and } \\
\text { gratification } \\
\text { theory }\end{array}$ & $\begin{array}{l}\text { Immediate feedback, } \\
\text { feeling of privacy, } \\
\text { responsiveness, social } \\
\text { presence, gratification }\end{array}$ \\
\hline
\end{tabular}




\begin{tabular}{|l|l|l|l|l|}
\hline in SNS & $\begin{array}{l}\text { sense of social } \\
\text { presence SNS } \\
\text { engender plays a } \\
\text { significant role in } \\
\text { fulfilling these } \\
\text { needs }\end{array}$ & & $\begin{array}{l}\text { of social connections } \\
\text { need, continued usage } \\
\text { intention. }\end{array}$ \\
& & & \\
\hline
\end{tabular}

\section{Theoretical foundation and hypotheses formulation}

For this study, the authors relied on cognitive dissonance theory (CDT) to explain social distancing and CAVSD. The motivation for this study was adapted from discontinuity theory, which is defined as a violation of any domain of functioning highly valued by individuals and causes cognitive dissonance (Zimbardo, 1999). To measure cognitive dissonance in social network usage behavior, the authors adapted social network intensity as an indicator (Shelton et. al., 2019).

\subsection{Cognitive dissonance theory (CDT)}

Festinger (1957) theorized that cognitive dissonance develops in the presence of multiple cognitive inconsistent elements. Under conditions of cognitive dissonance individuals find it difficult to take a stance on the side of one particular cognitive element. Cooper (2012) stated that cognitive discrepancy results when one cognition is the opposite of the previous cognitions. Cognitive dissonance can be lessened by eliminating dissonant cognitions, or adding more consistent cognitions, or lessening the significance of dissonant cognitions, or escalating the significance of consistent cognitions. Dissonance causes psychological discomfort and the individual is motivated to reduce it (Figure 1a). Festinger (1957) advocated the same expression of dissonance, to explain the inconsistency between individual cognition and the psychological uneasiness felt by individuals, namely, that behavior is attuned to line up with an individual's attitude, principles, or previous experiences. When individuals do not reduce this discrepancy, they experience an extended negative affective result and have a lingering psychological impact (Hinojosa et al., 2016). In the case of the COVID-19 outbreak and related social distancing, cognitive dissonance will have a psychological impact.

We tend to depend on CDT to describe individuals' social distancing due to regulatory norms. We examined how individuals' reluctance or willingness to distance from others has a psychological impact on them. The crux is that the cognitive appraisals of imposed social distancing will either be willingly accepted by individuals or unwillingly complied with, and will have some psychological impact that will find its expression in SNS usage intensity (Figure 1b). 
The Four-Step Process of Dissonance Arousal and Reduction

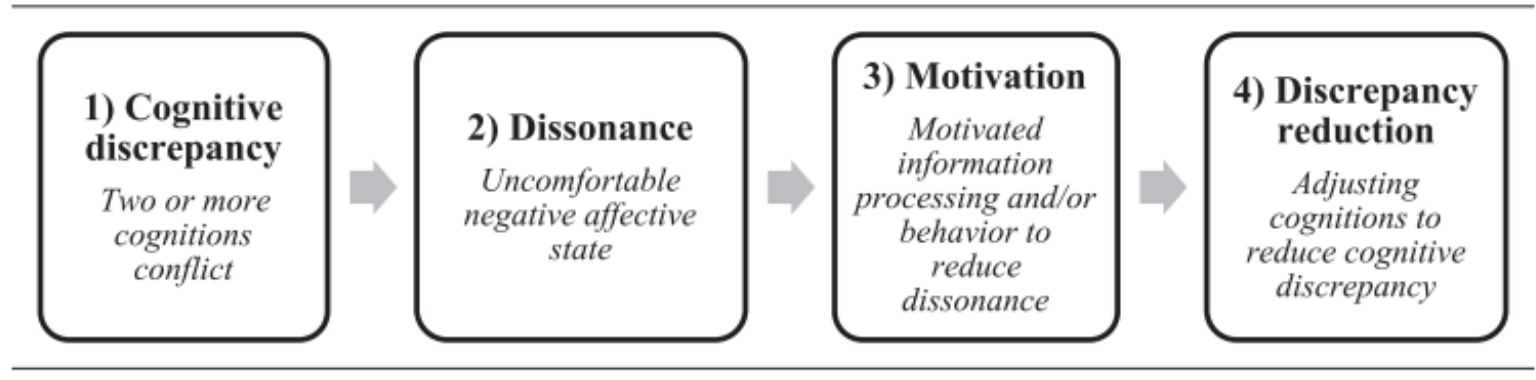

Figure 1a: The four-step process of dissonance arousal and reduction (Source: Authors' compilation adapted from Festinger's (1957) cognitive dissonance theory)

\subsection{Construct identification and description}

The review of the literature shows a clear gap in research in the area of social distancing from a non-medical psychological perspective. This study examined the networking behavior of people under the influence of social distancing during the COVID-19 pandemic and psychological impact of fear, loneliness, and stress in groups of people categorized by sex, age, and work status.

Lending from the four-step model of dissonance arousal and reduction, we present our study constructs as follows (Figure 1b):

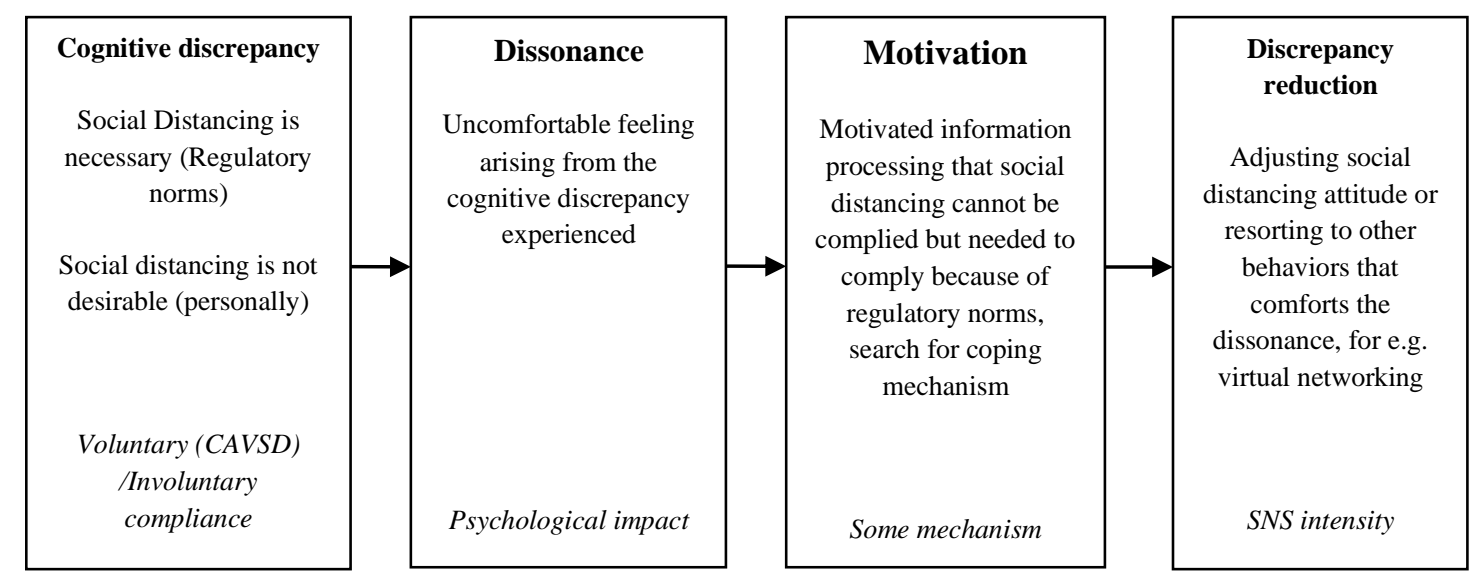

Figure 1b: The authors' adaptation of the four-step process of dissonance arousal and reduction

Since we were interested in the SNS usage intensity of individuals and how that is impacted by CAVSD mediated by the PI that individuals face due to social distancing, we constructed measures for each one of the variables based on an extensive review of literature. We first started with our predictor variable, CAVSD, for which we have identified social distancing attitude (SDA) and social distancing intention (SDI) as first-order latent variables. As a mediator variable we had PI as it could cause the incidence of the relationship between CAVSD and SNS usage intensity. We postulated that PI could be measured by the first-order latent variables: loneliness, cabin fever syndrome, COVID-19 fear, and traumatic stress (taken from literature, Appendix I). The outcome variable SNS usage intensity (first-order latent variable) was impacted by CAVSD. In a pandemic situation and a mandatory 
lockdown, people are psychologically impacted by the disruption to their normal life. This PI is affected by the individual's cognitive appraisal (voluntary/forced) of social distancing (Appendix I).

Prior research referred to the differential nature of SNS usage intensity for various categories of individuals based on sex, age, and work. Therefore, we endeavored to analyze the role of CAVSD on PI and SNS usage intensity on social network users (base model, shown in Figure 2) in a COVID-19 pandemic situation in India. Further we repeated the analysis for the same base model for subgroups, sex, age groups, and work status.

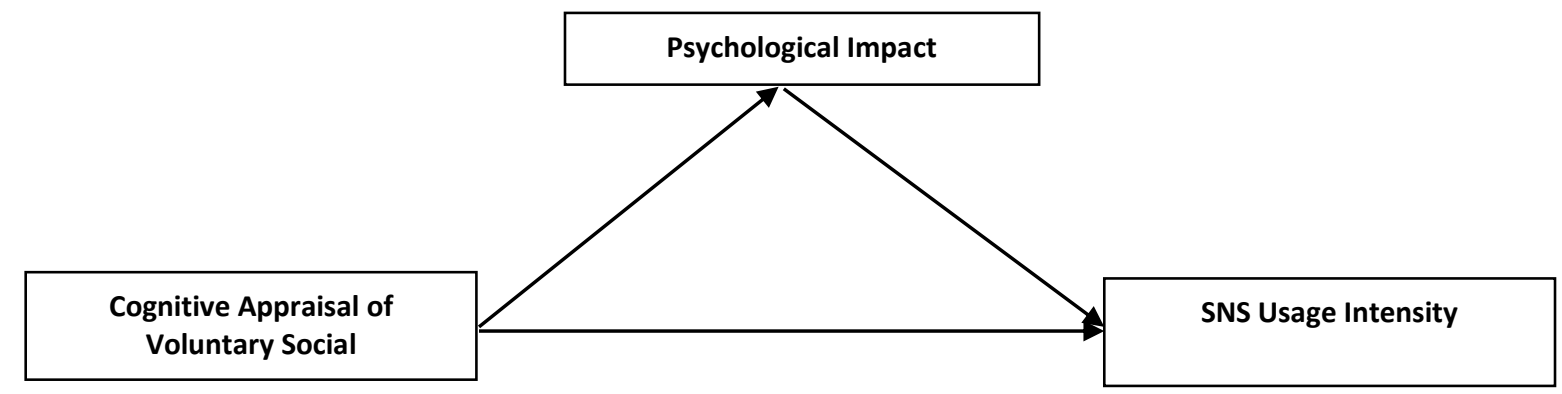

Figure 2: Proposed base model explaining the relationship between constructs

The summarized form of the constructs along with their definition and the measuring items are in Appendix I.

\subsection{Cognitive appraisal of voluntary social distancing compliance}

Cognitive factors impact behavioral intentions (Virick et al., 2015; Hewett et al., 2018); cognitive appraisal has a relationship with avoidant emotional coping (Alhurani et al., 2018); quarantine impacts psychological stress (Wang et al., 2011); and quarantine leads to distress (Wu et al., 2009). Cognitive appraisal is a core element of stress models. Cognitive dissonance leads to attempts to manage the stress arising from dissonance and leads to PI. The psychological demands of a particularly stressful situation result in coping mechanisms. Individuals' available choices of behavior are impacted by the resulting gains or losses from the choice.

In the context of social distancing, an individual's requirement to distance from people to combat the COVID-19 outbreak is appraised negatively, as this preventive measure brings challenges with it (Aravind, 2020, March 29). Individuals might respond to regulatory social distance willingly (when they support social distancing as a means to combat the spread of COVID-19) or are forced to do so (forced compliance). Forced compliance leads to a higher PI. Therefore, the construct draws from the four-step process of dissonance arousal and reduction, as stated above, i.e., first, cognitive discrepancy occurs, followed by dissonance, leading to motivated information processing, and finally resulting in discrepancy reduction. Mandatory social distancing is appraised as forced and creates a psychological impact. Therefore, in the context of mandatory social distancing, we hypothesize that:

H1: CAVSD is negatively related to the PI with respect to sex, age, and work status. 


\subsection{Cognitive appraisal and PI}

SNS assists individuals to unite, connect, interact, interrelate and share various information with their associates (Cheng et al., 2017), and communicating over SNS is considered as significant in the regular life of individuals (Alalwan et al., 2017). Research confirmed a positive relationship between psychological health and the use of smartphones by individuals (Rotondi et al., 2017). SNS paves the way for mass communication. Psychological distance is handled by bridging the gap of physical distances and social media help individuals to collaborate. Social media use has a relationship with depression (De Choudhury, 2013). The market research firm Nielsen posited that social media presence through SNS up-surged by $50 \%$ and COVID-19-related conversations reached 22.3 million by March 24 in India (Balram, 2020, March 28) as SNS users shared their fears and worries, psychological discomfort, and post photographs of family times and home-cooked meals over SNS (Guynn, 2020, April 3).

Social distancing creates a discomfort in the populace and results in coping mechanisms. Because of the COVID-19 outbreak, psychological impacts on the population have accentuated incidents of anxiety, insomnia, fear of financial crises, and stress and sleep disorders are common (O'Dair and Fazel, 2020). People are social beings that become psychologically distressed when confined at home so consequently reach out to people through social media platforms. To stay connected, people engage in Facebook, WhatsApp, Twitter, LinkedIn, and organize Zoom happy hours with their social network (Dolgin and Fazel, 2020). Thus, we hypothesized that:

H2: PI partially mediates CAVSD and SNS usage intensity with respect to sex, age, and work status.

\subsubsection{CAVSD and SNS Usage Intensity}

Social distancing involves purposely increasing the physical distance between individuals in the society, to avoid spreading illness and at the same time causing psychological discomfort. In such a scenario, instead of meeting people in person, people choose to meet their associates using electronic devices (Lockerd Maragakis, 2020, March 10). Tensions and anxiety pile up into an unhelpful range during social distancing, and people are affected by an information overload or infodemic (Ajmal, 2020, April 10). There is also a fear of missing out. CDT could also explain people's search for more information on SNS to resolve dissonance discomfort, although a reduction in dissonance may not always yield good results (Beauvois and Joule, 2019). The immersion into stories of the pandemic to learn how others are behaving in the situation across the globe leads to social media concentration; this was marked by a bump in searches for the keyword 'coronavirus' in Google and discussions about this soared on SNS (Banerjee 2020, March 27). The pandemic increased the need to share information. There was a rise in social media posts sharing messages, photographs, and news items (Parikh et al., 2020) and the intention to remain connected increased. Hence, we hypothesized that:

\section{H3: CAVSD positively impacts SNS usage intensity with respect to sex, age, and work status.}

Based on the literature review and the hypotheses presented above, the proposed model of this study is depicted in Figure 3 below. The model explores the inter-relationship between the three main constructs used in this study, viz., the relationship between CAVSD, SNS Usage Intensity, and PI. The development of all the first order variables have been taken on the basis of literature review as presented above. 


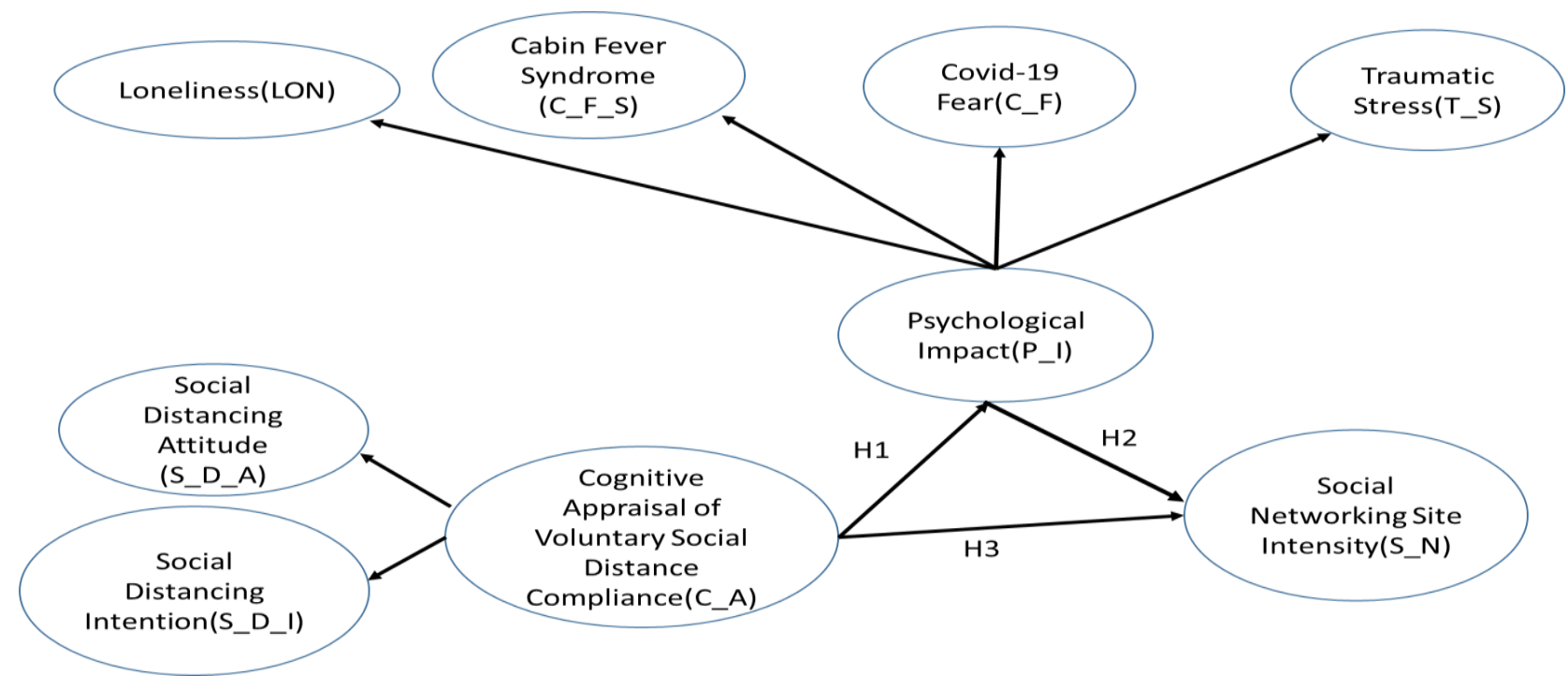

Figure 3: A proposed conceptual model (Source: Authors' compilation based on a literature review)

\section{Methodology}

\subsection{Questionnaire development}

An extant literature review was done to develop the questionnaire using the constructs identified earlier. A 5-point Likert scale (strongly disagree to strongly agree) was used throughout the questionnaire. Data were collected from social media users in major cities across India during the COVID-19 outbreak using a snowball sampling technique. Since our research methodology required us to elicit responses with an interval of ten days, we had to stop looking for additional responses at a particular point in time and to allow the snowball technique to continue indefinitely. This resulted in a total of 486 responses collected through an online survey platform. Out of these, 477 responses were complete in all the aspects, and nine responses were incomplete and discarded. We considered this an adequate sample size (Westland, 2010). Further, since all the subgroups we analyzed exceeded the minimum number of ten (Roscoe and Byars, 1971), we felt our goodness-of-fit tests for Chi-square were valid.

\subsection{Participants}

For the subgroup study, we divided the respondents into three age groups, viz., 0-20 years old, 21-35 years old, and above 35 years old. Our sample comprised 10.1\% in the 0-20 years old group (with 17 years being the minimum age), 64.1\% in the 21-35 years old group, and $25.8 \%$ in the $>35$ years old group. We also analyzed the sample by sex: $52.83 \%$ female and $47.17 \%$ male participants (Table 2). To determine if there were significant differences between respondents based on their work status, we divided the whole sample into three groups: WFH, NWFH and SLO. Our sample consisted of 35\% WFH, 16.4\% NWFH, and $48.6 \%$ SLO. We excluded people working in essential services, who had to leave home for work during the pandemic, as this group was not subject to confinement at home. Table 2 provides a summary of these demographic variables. After analyzing the tabulated data, we found that there was a concentration of respondents in the 21-35 years group and in the SLO categories, with a relatively even distribution among men and women. 


\subsection{Data Analysis}

The data were analyzed using structural equation modeling (SEM). Confirmatory factor analysis (CFA) was used to measure the latent variables. CAVSD was the second-order latent variable, which was measured by the first-order latent variables social distancing attitude and social distancing intention. Loneliness, cabin fever syndrome, fear of COVID-19, and traumatic stress (Figure 3) were the first-order latent variables for the second-order latent variable PI. The dependent variable was a first-order latent variable called SNS usage intensity. The loadings of the measurement of the latent variables showed adequate factor loadings (Table 3).

Cross-sectional studies, where data are collected for respondents through questionnaires tend to exhibit common method bias (CMB) (Podsakoff et al., 2003). To reduce the CMB effect, we first developed the observed variables in a way that it included reverse item questions, which are a good method of reducing CMB. Furthermore, we collected our data so that only independent variables were collected at one point in time. Data on the measured mediator variable and the dependent variable were collected after a gap of 10 days. This also reduced CMB (Atwater and Carmeli, 2009). Since we collected data for the mediator and dependent variables from respondents at the same point in time, we tested for residual effects of CMB in the data. We conducted a Harman's single-factor analysis (Shkoler and Tziner, 2017) and exploratory factor analysis (EFA) to confirm that CMB was absent.

Table 2: Demographic representation of the number of respondents $(\mathrm{N}=477)$ in terms of the overall sample, sex, age and work status

\begin{tabular}{|l|c|c|c|c|c|c|c|}
\hline & Total N & $\begin{array}{c}\text { 0 to 20 } \\
\text { years } \\
\text { old }\end{array}$ & $\begin{array}{c}\text { 21 to 35 } \\
\text { years } \\
\text { old }\end{array}$ & $\begin{array}{c}\text { 36 to 50 } \\
\text { years } \\
\text { old }\end{array}$ & WFH & NWFH & SLO \\
\hline Male & 225 & 17 & 139 & 69 & 78 & 40 & 107 \\
\hline Female & 252 & 31 & 167 & 54 & 89 & 38 & 125 \\
\hline Total & 477 & 48 & 306 & 123 & 167 & 78 & 232 \\
\hline $\begin{array}{l}\text { Respondents } \\
\text { \% }\end{array}$ & 100 & 10.1 & 64.1 & 25.8 & 35 & 16.4 & 48.6 \\
\hline
\end{tabular}

\subsection{Path model testing}

The Lavaan package was used to analyze the data in R Studio (Oberski, 2014; Rosseel et al., 2017). Structural equation modelling was used to analyze the measurement model as well as a path model for testing the hypotheses. There were seven first-order and two second-order constructs used in the model.

\subsubsection{Measurement model}

The objectives of this research were to explore the effect of CAVSD on SNS usage intensity, to examine the impact of PI on SNS usage intensity, and the effect of CAVSD on PI. Before applying structural equation modelling to test the hypothesis, we performed a measurement analysis to check the constructs' reliability, uni-dimensionality, convergence validity, and discriminant validity, as well as the goodness-of-fit indices. EFA was used to measure the constructs and the factor loadings, and other fit indices were as per standards (Tables 3 and 4). 
Table 3: Measurement model

\begin{tabular}{|c|c|c|c|c|c|}
\hline Constructs & Items & Estimates & $\begin{array}{l}\text { Std. } \\
\text { error }\end{array}$ & Z-value & $\mathbf{P}(>|\mathbf{z}|)$ \\
\hline \multirow{4}{*}{$\begin{array}{c}\text { Loneliness (LON) } \\
\text { First-order latent variable }\end{array}$} & L1 & 1.000 & & & \\
\hline & L2 & 1.290 & 0.070 & 18.469 & 0.000 \\
\hline & L3 & 1.195 & 0.068 & 17.611 & 0.000 \\
\hline & L4 & 1.097 & 0.669 & 15.994 & 0.000 \\
\hline \multirow{5}{*}{$\begin{array}{c}\text { Cabin fever syndrome } \\
\left(\mathbf{C}_{-} \mathbf{F}_{-} \mathbf{S}\right) \\
\text { First-order latent variable }\end{array}$} & CFS1 & 1.000 & & & \\
\hline & CFS2 & 0.992 & 0.056 & 17.800 & 0.000 \\
\hline & CFS3 & 0.634 & 0.059 & 10.753 & 0.000 \\
\hline & CFS4 & 0.839 & 0.053 & 15.963 & 0.000 \\
\hline & CFS5 & 0.830 & 0.055 & 15.059 & 0.000 \\
\hline \multirow{4}{*}{$\begin{array}{l}\text { COVID-19 fear }\left(\mathbf{C} \_\mathbf{I}\right) \\
\text { First-order latent variable }\end{array}$} & COVID1 & 1.000 & & & \\
\hline & COVID2 & 0.748 & 0.048 & 15.710 & 0.000 \\
\hline & COVID3 & 1.016 & 0.054 & 18.783 & 0.000 \\
\hline & COVID4 & 1.126 & 0.058 & 19.334 & 0.000 \\
\hline \multirow{5}{*}{$\begin{array}{l}\text { Traumatic stress (T_S) } \\
\text { First-order latent variable }\end{array}$} & TS1 & 1.000 & & & \\
\hline & TS2 & 1.141 & 0.071 & 16.116 & 0.000 \\
\hline & TS3 & 1.086 & 0.067 & 16.098 & 0.000 \\
\hline & TS4 & 0.846 & 0.064 & 13.249 & 0.000 \\
\hline & TS5 & 0.447 & 0.060 & 7.404 & 0.000 \\
\hline \multirow{4}{*}{$\begin{array}{l}\text { Psychological impact }(\mathbf{P} \mathbf{I}) \\
\text { Second-order latent variable }\end{array}$} & Loneliness (LON) & 1.000 & & & \\
\hline & Cabin fever syndrome (C_F) & 1.372 & 0.148 & 9.257 & 0.000 \\
\hline & COVID-19 fear (C_I) & 0.944 & 0.116 & 8.138 & 0.000 \\
\hline & Traumatic stress (T_S) & 1.157 & 0.132 & 8.171 & 0.000 \\
\hline \multirow{3}{*}{$\begin{array}{l}\text { Social distancing attitude } \\
\text { (S_D_A) } \\
\text { First-order latent variable }\end{array}$} & AT1 & 1.000 & & & \\
\hline & AT2 & 1.072 & 0.072 & 14.822 & 0.000 \\
\hline & AT3 & 1.121 & 0.053 & 21.105 & 0.000 \\
\hline \multirow{3}{*}{$\begin{array}{c}\text { Social distancing intention } \\
\text { (S_D_I) } \\
\text { First-order latent variable }\end{array}$} & IN1 & 1.000 & & & \\
\hline & IN2 & 0.920 & 0.055 & 16.659 & 0.000 \\
\hline & IN3 & 0.994 & 0.050 & 20.036 & 0.000 \\
\hline \multirow{2}{*}{$\begin{array}{c}\text { Cognitive appraisal of } \\
\text { voluntary social distance } \\
\text { compliance (C_A) } \\
\text { Second-order latent variable } \\
\end{array}$} & Social distancing attitude (S_D_A) & 1.000 & & & \\
\hline & Social distancing intention (S_D_I) & 0.790 & 0.206 & 3.833 & 0.000 \\
\hline \multirow{4}{*}{$\begin{array}{l}\text { SNS usage intensity }\left(\mathbf{S} \_\mathbf{N}\right) \\
\text { First-order latent variable }\end{array}$} & SNI1 & 1.000 & & & \\
\hline & SNI2 & 0.961 & 0.049 & 19.434 & 0.000 \\
\hline & SNI3 & 0.777 & 0.061 & 12.676 & 0.000 \\
\hline & SNI4 & 0.743 & 0.062 & 11.977 & 0.000 \\
\hline
\end{tabular}

\subsubsection{Model validity}

To confirm the absence of CMB, Harman's single-factor resulted in a total of $15.8 \%$ of the explained variance which was far below the expected 33\% (MacKenzie and Podsakoff, 2012). The reliability test of the scale showed adequate reliability (Appendix I). The fit indices of the measurement and path models (Table 4) showed a good model fit for the prediction. The values of the construct reliability (CR), average variance extracted (AVE), maximum shared variance (MSV), and average shared variance (ASV) were as per the expected cut-off values.

Reliability: CR > 0.7

Convergent Validity: AVE $>0.5$

Discriminant Validity: MSV $<$ AVE; ASV $<$ AVE 
Square root of AVE greater than inter-construct correlations (see Table 5).

Table 4: Model fit indices

\begin{tabular}{|l|c|c|l|}
\hline \multicolumn{1}{|c|}{$\begin{array}{c}\text { Fit indices' analysis of the } \\
\text { research model }\end{array}$} & $\begin{array}{c}\text { Model } \\
\text { fit }\end{array}$ & $\begin{array}{c}\text { Reference index } \\
\text { (Upadhyayand } \\
\text { Kumar, 2020 })\end{array}$ & \multicolumn{1}{c|}{ Source } \\
\hline$\chi^{2} / \mathrm{df}$ & 2.16 & $<3$ & $\begin{array}{l}\text { (Barrett, 2007; Falke } \text { et al., 2020; Oberski, } \\
\text { 2014; Rosseel } \text { et al., 2017) }\end{array}$ \\
\hline Goodness-of-fit index (GFI) & 0.911 & $>0.9$ & $\begin{array}{l}\text { (Barrett, 2007; Falke } \text { et al., 2020; Oberski, } \\
\text { 2014; Rosseel GTM ., 2017) }\end{array}$ \\
\hline $\begin{array}{l}\text { Adjusted goodness-of-fit index } \\
\text { (AGFI) }\end{array}$ & 0.921 & $>0.9$ & $\begin{array}{l}\text { (Barrett, 2007; Falke } \text { et al., 2020; Oberski, } \\
\text { 2014; Rosseel } \text { et al., 2017) }\end{array}$ \\
\hline Normed fit index (NFI) & 0.913 & $>0.9$ & $\begin{array}{l}\text { (Barrett, 2007; Falke } \text { et al., 2020; Oberski, } \\
\text { 2014; Rosseel } \text { et al., 2017) }\end{array}$ \\
\hline $\begin{array}{l}\text { Bentler-Bonnet non-normed fit } \\
\text { index (NNFI) }\end{array}$ & 0.933 & $>0.9$ & $\begin{array}{l}\text { (Barrett, 2007; Falke } \text { et al., 2020; Oberski, } \\
\text { 2014; Rosseel } \text { et al., 2017) }\end{array}$ \\
\hline Tucker-Lewis index (TLI) & 0.933 & $>0.9$ & $\begin{array}{l}\text { (Barrett, 2007; Falke } \text { et al., 2020; Oberski, } \\
\text { 2014; Rosseel } \text { et al., 2017) }\end{array}$ \\
\hline Comparative fit index (CFI) & 0.94 & $\begin{array}{l}\text { (Barrett, 2007; Falke } \text { et al., 2020; Oberski, } \\
\text { 2014; Rosseel } \text { et al., 2017) }\end{array}$ \\
\hline $\begin{array}{l}\text { Standardized root mean square } \\
\text { error of approximation (SRMR) }\end{array}$ & 0.049 & $\begin{array}{l}\text { (Barrett, 2007; Falke } \text { et al., 2020; Oberski, } \\
\text { 2014; Rosseel } \text { et al., 2017) }\end{array}$ \\
\hline
\end{tabular}

Table 5: Constructs correlation matrix (diagonal values represent square roots of AVE)

\begin{tabular}{|c|c|c|c|c|c|c|c|c|c|}
\hline & 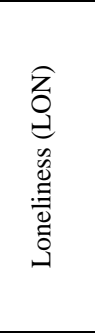 & 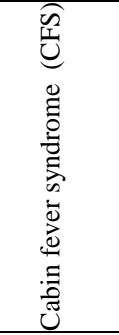 & 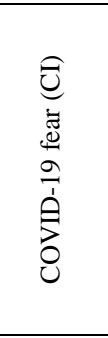 & 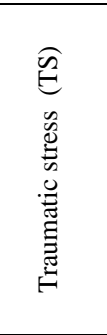 & 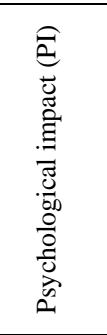 & 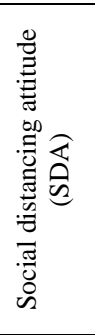 & 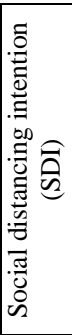 & 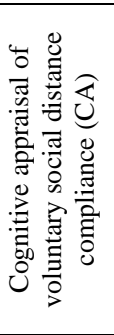 & 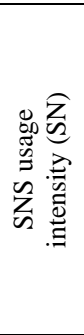 \\
\hline Loneliness (LON) & 0.93 & & & & & & & & \\
\hline Cabin fever syndrome (CFS) & 0.52 & 0.75 & & & & & & & \\
\hline COVID-19 fear(CI) & 0.38 & 0.45 & 0.96 & & & & & & \\
\hline Traumatic stress (TS) & 0.48 & 0.57 & 0.426 & 0.87 & & & & & \\
\hline Psychological impact (PI) & 0.66 & 0.78 & 0.58 & 0.735 & 0.95 & & & & \\
\hline Social distancing attitude (SDA) & -0.04 & -0.055 & -0.041 & -0.052 & -0.07 & 0.96 & & & \\
\hline Social distancing intention (SDI) & -0.03 & -0.042 & -0.032 & -0.04 & -0.054 & 0.802 & $\begin{array}{c}0.9 \\
7 \\
\end{array}$ & & \\
\hline $\begin{array}{l}\text { Cognitive appraisal of voluntary } \\
\text { social distance compliance (CA) }\end{array}$ & -0.04 & -0.05 & -0.04 & -0.051 & -0.069 & 0.68 & $\begin{array}{c}0.7 \\
8\end{array}$ & 0.81 & \\
\hline SNS usage intensity (SN) & 0.21 & 0.25 & 0.19 & 0.24 & 0.32 & 0.15 & $\begin{array}{c}0.1 \\
2\end{array}$ & 0.15 & 0.87 \\
\hline
\end{tabular}

\subsection{Results of the path model}

The path model represents the linear regressions of the hypotheses; its effect size and pvalues are shown in Figure 4.

The three regression equations for the full sample of 477 respondents are reported in Table 6. The first regression equation shows the results of the dependent variable PI regressed on the CAVSD. The second regression equation shows the results of the dependent variable SNS 
Usage Intensity regressed on the independent variable PI. The third regression equation shows the results of the dependent variable SNS usage intensity regressed on the independent variable CAVSD.

We found that the first hypothesis (H1) was not supported, although the effect size $(-0.069)$ was in the predicted direction (negative). We found support for both the second (H2) and third hypotheses (H3) with effect sizes of 0.535 for PI and 0.277 for CAVSD, respectively (Figure 4, Table 6). These results implied that PI was a partially mediating variable between CAVSD and SNS usage intensity.

Table 6: Regression of the path model, overall sample

\begin{tabular}{|l|l|l|l|l|}
\hline & Estimate & Std. error & $\mathbf{z}$-value & $\mathbf{P}(>|\mathbf{z}|)$ \\
\hline Psychological impact predicted by & & & & \\
\hline 1. CAVSD (H1) & -0.069 & 0.057 & -1.198 & 0.231 \\
\hline SNS usage intensity predicted by & & & & \\
\hline 2. Psychological impact (H2) & 0.535 & 0.095 & 5.625 & 0.000 \\
\hline 3. CAVSD (H3) & 0.277 & 0.100 & 2.781 & 0.005 \\
\hline
\end{tabular}

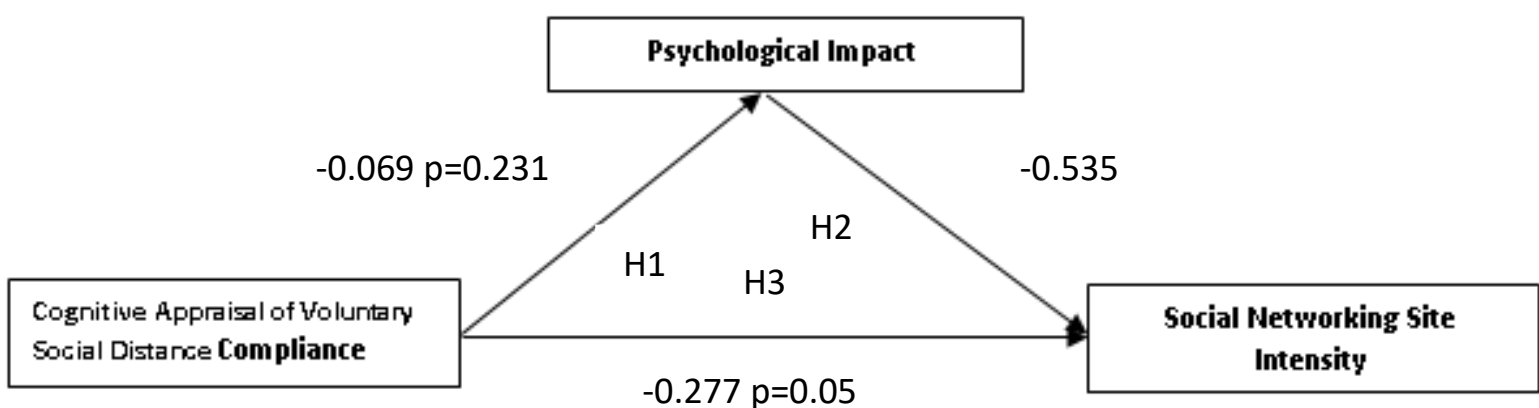

Figure 4: Path model for the overall sample

\subsubsection{Group analysis}

\subsubsection{Sex}

Next, based our literature review (Section 2), we investigated if these results held for the various categories identified in previous research. Kimbrough et al. (2013) found that SNS was used more frequently by women, while Fallows (2005) posited that this difference could be due to the different motivations men and women have to use the internet. Similarly, Taylor (2009) found higher usage of Facebook by women. Accordingly, we repeated our testing on the men and women in the sample to see if COVID-19 presented a similar pattern. The results of this analysis are given in Figure 5. The model used the Lavaan CFA function grouped by the variable "Sex" in the data set. The modified path analysis by sex (male, $n=225$ and female, $n=252$ ) revealed that for women, the PI was affected by CAVSD with an effect size of -0.221 , which was statistically significant at the $5 \%$ level. However, in the case of men, we 
found that CAVSD had an opposite affect on PI to what was hypothesized, although not statistically significant (effect size=0.009). Thus, H1 held for women but not for men.

Looking at the results of the second hypothesis (H2) we found statistically significant effect sizes for both men (0.562) and women (0.452), which supported $\mathrm{H} 2$ and showed that PI partially mediated CAVSD and SNS usage intensity for both men and women. Considering the result for the third hypothesis (H3), we found that the results supported the hypothesis for women with an effect size of 0.279 , which was statistically significant at $5 \%$. However, for men, the effect size was smaller and marginally significant $(\mathrm{p}=0.075)$. CAVSD, therefore, positively impacts SNS usage intensity even when the sample is divided by gender. The fit statistics and the $\mathrm{R}^{2}$ values of the model are listed in Tables 7 and 8 . The fit statistics showed adequate model fit for sex.

Table 7. Model fit statistics of the path model group, Sex

\begin{tabular}{|l|l|}
\hline Model test baseline model: & \\
\hline Minimum function test statistic & 7498.404 \\
\hline Degrees of freedom & 756 \\
\hline P-value & 0.000 \\
\hline User model versus baseline model: & \\
\hline Comparative fit index (CFI) & 0.929 \\
\hline Tucker-Lewis index (TLI) & 0.921 \\
\hline Root mean square error of approximation: & \\
\hline RMSEA & 0.054 \\
\hline P-value RMSEA <= 0.05 & 0.0504 \\
\hline Standardized root mean square residual: & \\
\hline SRMR & 0.076 \\
\hline
\end{tabular}

Table 8. $R^{2}$ values of the path model group, Sex

\begin{tabular}{|l|c|c|}
\hline Variables & Female & Male \\
\hline $\begin{array}{l}\text { Psychological impact Cognitive appraisal of } \\
\text { voluntary social distance compliance }\end{array}$ & 0.829 & 0.398 \\
\hline $\begin{array}{l}\text { SNS usage intensity Cognitive appraisal of } \\
\text { voluntary social distance compliance }\end{array}$ & 0.68 & 0.555 \\
\hline SNS usage intensity Psychological impact & 0.287 & 0.377 \\
\hline
\end{tabular}



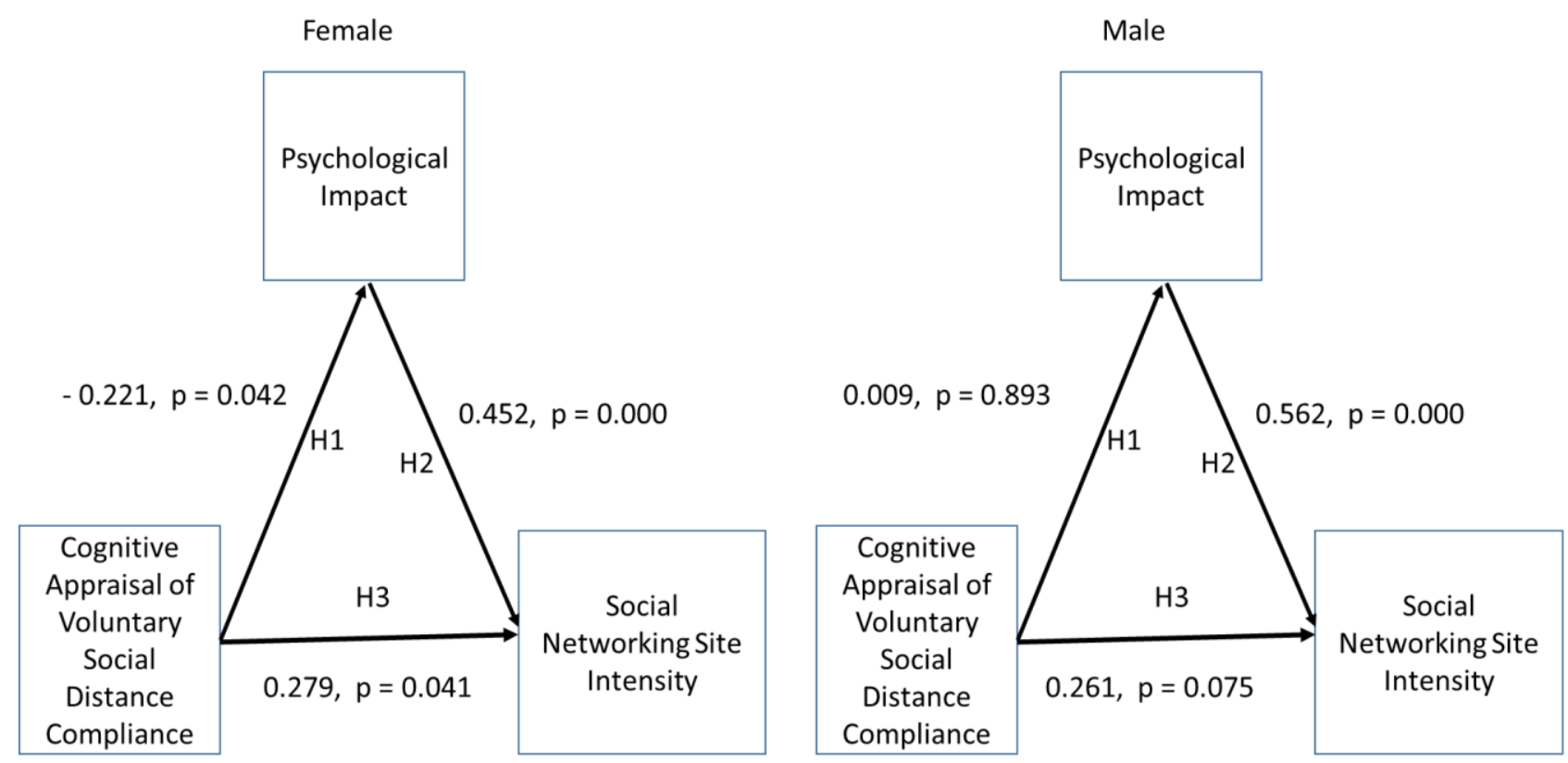

Figure 5. Path model by sex grouping

\subsubsection{Age}

Concerning age groups, we tested the first hypothesis (H1), that CAVSD was negatively related to PI. The effect direction was negative as hypothesized, for the age groups $<20$ years old and 21-35 years old, but not statistically significant. The effect direction was positive for the third age group, but again not statistically significant. Concerning our second hypothesis (H2), we found strong support for the 21-35 years old group, with an effect size of 0.752 and statistical significance. While the effect direction was positive, as hypothesized for the other age groups, they were not statistically significant (Figure 6). Thus, we found partial support for $\mathrm{H} 2$, that PI partially mediates CAVSD and SNS usage intensity. Regarding our results for the third hypothesis (H3), we found support for the age group $<20$ years old, with an effect size of 1.319 and statistic significance. Similar to the results for the second hypothesis, in $\mathrm{H} 3$ the other age groups had an effect direction as predicted, but not statistically significant. Again, we had partial support for H3: CAVSD positively impacts SNS intensity. The fit statistics and the $\mathrm{R}^{2}$ values of the model are listed in the Tables 9 and 10 . The fit statistics show adequate model fitness for the group Age.

Table 9. Model fit statistics of the path model group, Age

\begin{tabular}{|l|l|}
\hline Model fit test statistic & 2401.559 \\
\hline Degrees of freedom & 1364 \\
\hline P-value (Chi-square) & 0.000 \\
\hline Model test baseline model: & \\
\hline Minimum function test statistic & 8934.227 \\
\hline Degrees of freedom & 1512 \\
\hline
\end{tabular}




\begin{tabular}{|l|l|}
\hline P-value & 0.000 \\
\hline User model versus baseline model: & \\
\hline Comparative fit index (CFI) & 0.96 \\
\hline Tucker-Lewis index (TLI) & 0.945 \\
\hline Root mean square error of approximation: & \\
\hline RMSEA & 0.06 \\
\hline Standardized root mean square residual: & \\
\hline SRMR & 0.07 \\
\hline
\end{tabular}

Table 10. $\mathbf{R}^{2}$ values of the path model group, Age

\begin{tabular}{|l|c|c|c|}
\hline \multicolumn{1}{|c|}{ Variables } & $\begin{array}{c}\text { 0 to 20 } \\
\text { years old }\end{array}$ & $\begin{array}{c}\text { 21 to 35 } \\
\text { years } \\
\text { old }\end{array}$ & >35 years \\
\hline $\begin{array}{l}\text { Psychological impact Cognitive appraisal of } \\
\text { voluntary social distance compliance }\end{array}$ & 0.211 & 0.36 & 0.366 \\
\hline $\begin{array}{l}\text { SNS usage intensity Cognitive appraisal of } \\
\text { voluntary social distance compliance }\end{array}$ & 0.401 & 0.668 & 0.552 \\
\hline SNS usage intensity Psychological impact & 0.768 & 0.349 & 0.22 \\
\hline
\end{tabular}

Group Analysis of Model (Age)

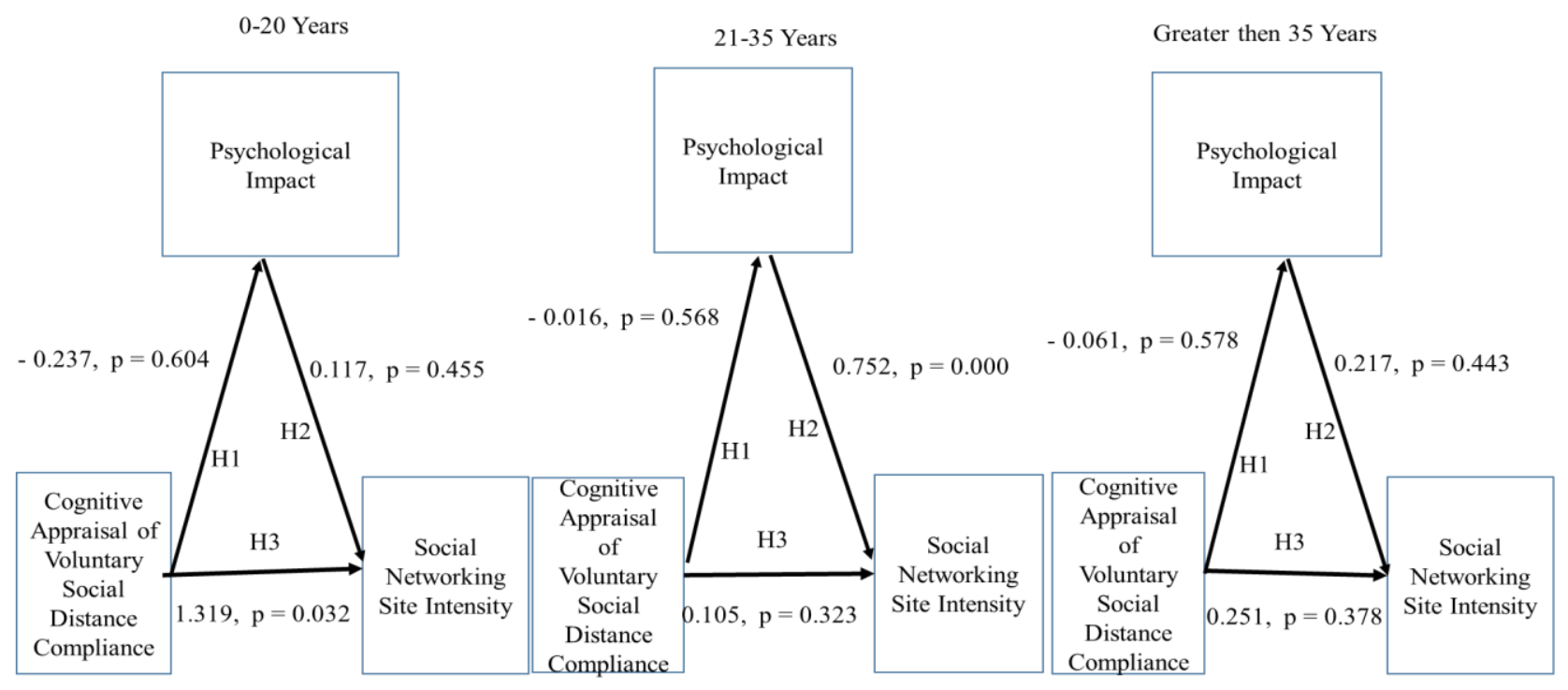

Figure 6. Path model by age grouping

\subsubsection{Work status}

Our third grouping was based on work status. Since our sample consisted of $48 \%$ of students learning online and this demographic had a higher propensity to utilize SNS. We decided to analyze the data based on whether the respondent was a student learning online or not. However, since the non-student respondent would either be working from home or not, we 
decided to divide the full sample into three categories, 1) working from home (WFH), 2) not working from home (NWFH), and 3) students learning online (SLO).

The H1 was related to the impact of CAVSD on PI. We found the effect to be in the hypothesized direction but not statistically significant in any sub-group, as in the full sample. Regarding our second hypothesis (H2) on the effect of PI on SNS Usage Intensity, we found that the result for the full sample held for each subset of work status sub-samples although the effect sizes differed ( 0.453 for WFH, 0.862 for NWFH, and 0.511 for SLO). The NWFH respondents appeared to be more affected by PI than the other two categories of respondents. Thus, PI partially mediated CAVSD and SNS Usage Intensity. Regarding the results for the test for the third hypothesis (H3), we found the effect size for SLO was 0.268, which was statistically significant, while the effects of the other two groups were in the hypothesized direction (positive), but not statistically significant (Figure 7). Therefore, CAVSD positively impacted SNS Usage Intensity for the SLO group. The fit statistics and the $\mathrm{R}^{2}$ values of the model are listed in the Tables 11 and 12. The fit statistics show adequate model fitness for the group work status.

\section{Table 11. Model fit statistics of the path model group, Work Status}

\begin{tabular}{|l|l|}
\hline Model fit test statistic & 1707.34 \\
\hline Degrees of freedom & 1023 \\
\hline P-value (Chi-square) & 0.000 \\
\hline User model versus baseline model: & 0.902 \\
\hline Comparative fit index (CFI) & 0.90 \\
\hline Tucker-Lewis index (TLI) & 0.065 \\
\hline RMSEA & 0.000 \\
\hline P-value RMSEA <=0.05 & \multicolumn{2}{|l|}{} \\
\hline Standardized root mean square residual: & 0.082 \\
\hline SRMR & \multicolumn{2}{|l|}{} \\
\hline
\end{tabular}

Table 12: $\mathbf{R}^{2}$ values of the path model group, Work Status

\begin{tabular}{|l|l|l|l|}
\hline & \multicolumn{1}{|c|}{ WFH } & NWFH & \multicolumn{1}{|c|}{ SLO } \\
\hline $\begin{array}{l}\text { Psychological Impact } \sim \text { Cognitive Appraisal of Voluntary } \\
\text { Social Distancing }\end{array}$ & 0.414 & 0.365 & 0.534 \\
\hline $\begin{array}{l}\text { Social Networking Intensity Cognitive Appraisal of } \\
\text { Voluntary Social Distancing }\end{array}$ & 0.621 & 0.588 & 0.768 \\
\hline Social Networking Intensity Psychological Impact & 0.77 & 0.952 & 0.768 \\
\hline
\end{tabular}



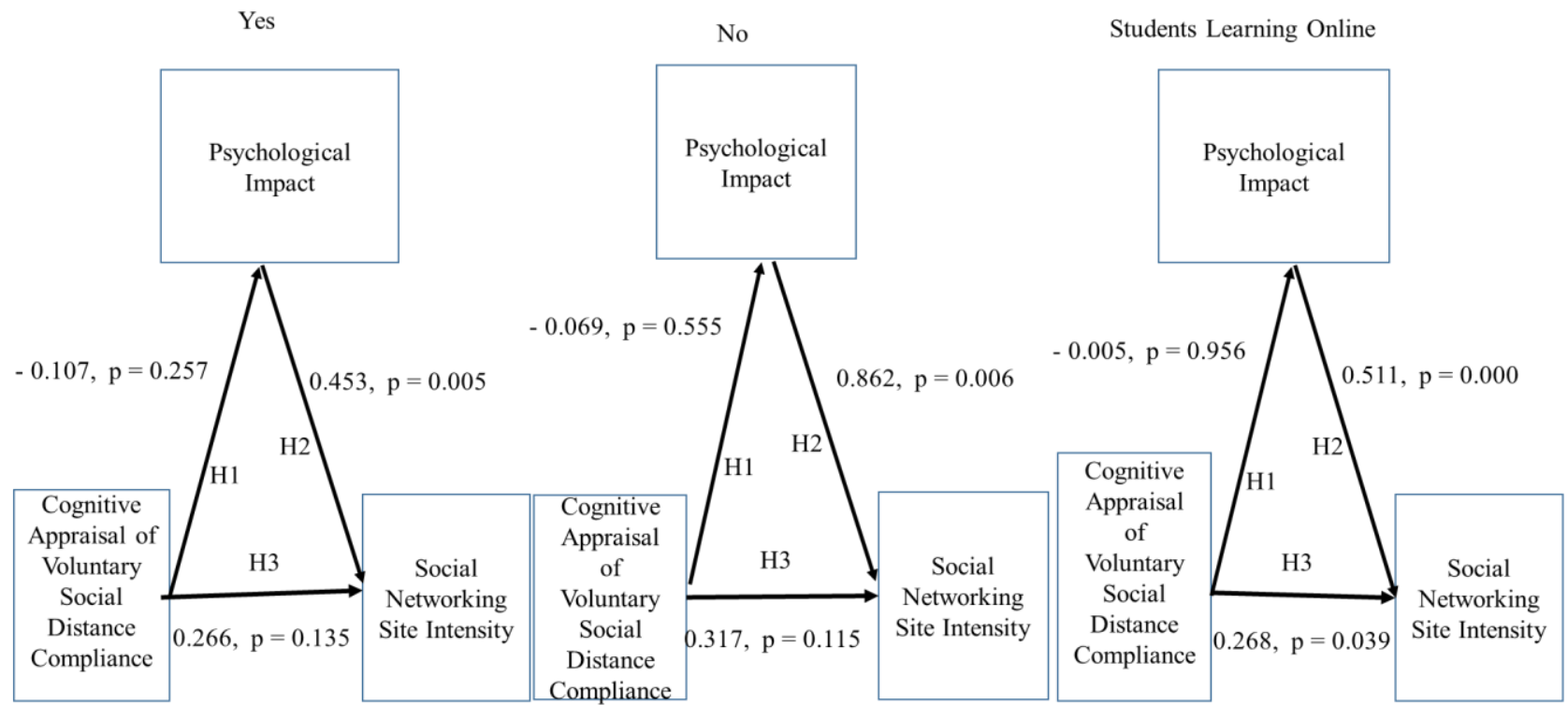

Figure 7. Path model by Work Status grouping

Table 13. Results of hypotheses

\begin{tabular}{|c|l|l|}
\hline $\begin{array}{c}\text { Hypothesis } \\
\text { no. }\end{array}$ & \multicolumn{1}{|c|}{ Hypothesis statement } & \multicolumn{1}{|c|}{ Results } \\
\hline $\mathrm{H} 1$ & $\begin{array}{l}\text { CAVSD is negatively related to PI with respect to gender, } \\
\text { age, and work status. }\end{array}$ & Not significant \\
\hline $\mathrm{H} 2$ & $\begin{array}{l}\text { PI partially mediates CAVSD and SNS usage intensity } \\
\text { concerning gender, age, and work status. }\end{array}$ & Supported \\
\hline $\mathrm{H} 3$ & $\begin{array}{l}\text { CAVSD positively impacts SNS usage intensity with respect } \\
\text { to sex, age, and work status. }\end{array}$ & Supported \\
\hline
\end{tabular}

\section{Discussion}

The present study investigated the relationship between CAVSD and PI on individuals (H1), examined the relationship between CAVSD and SNS usage intensity (H2), and studied the mediating role of PI in CAVSD and SNS usage intensity (H3). Participants were 477 Indian social network users categorized by sex, age, and work status. The results of our analysis are summarized in Table 13.

Pandemics and preventive social distancing have been studied from a medical perspective regarding disease containment (Reluga, 2010; Valdez et al., 2012; Adolph et al., 2020; Sharma et al., 2020; Wilder-Smith and Freedman, 2020), but few studies have focused on ethnic or racial social distancing (Yogeeswaran and Dasgupta, 2014; Ramasubramanian et $a l ., 2017$ ) and social distancing concerning mental illness (Seaton and Piel, 2017; Lundquist and Gurung, 2019), and even less have looked at social distancing and human PI. 
This study is the first attempt to explore how CAVSD affects individuals psychologically. But, we found that CAVSD was not a significant predictor for PI (H1) in our full sample. In terms of sex grouping, we found support for H1 in that CAVSD's impact on PI was statistically significant in women, while for men, we found the effect was in the opposite direction, although not statistically significant. As CAVSD was supposed to determine how social distancing was adopted by individuals, the present study could not link CAVSD to PI. Considering a classification based on age groups, we did not find any statistically significant results for $\mathrm{H} 1$, moreover, results were in the opposite direction to what we hypothesized for older respondents, i.e., those $>35$ years old. The results for younger respondents were as hypothesized but not statistically significant.

In the work status categories we found that CAVSD had a negative impact on PI as hypothesized, albeit, without statistical significance. The effect sizes across work status categories were quite different from each other. Social distancing intention and attitude in the form of cognitive appraisal were related to individual psychology. There is a chance that people perceive these differences and feel the psychological impact differently. One of the most significant factors that health behavior models propose is that the relationship between perceived risk and intention to avoid risk might be positive or negative (Brewer et al., 2007). The present study found that CAVSD had not been effective in determining the PI of people during the COVID-19 pandemic, probably because people accepted the hazards of social proximity and accepted social distancing for health reasons. This implies that respondents in the study accepted that, as a containment strategy, social distancing was an effective measure to contain an epidemic (Lewnard and Lo, 2020). Attitude towards social distancing by a population might be affected by their perceived risk of disease occurrence (Reluga et al., 2006) or it might be a result of what individuals learn from their neighbors (Chen, 2009); this eventually impacts the psychological framework of individuals.

The COVID-19 pandemic created a perception of risk and so accepting social distancing voluntarily was not psychologically impactful. This is in line with previous studies that talk about social distancing intention as a valid reaction to the hazards of an infectious disease (Maharaj and Kleczkowski, 2012). Thus, a cognitive appraisal determines whether social distancing is favorably supported or forcibly imposed. Though Cacioppo et al. (2011) advocates that social isolation coupled with or without loneliness has serious health effects, our study could only find a connection between CAVSD and PI in women. For social control and context, there appears to be a difference between men and women (Brody and Hall, 2008). Women also have a stronger social network (Veroff et al., 1981), which was confirmed by $\mathrm{H} 1$ being significant only for women. Mehta et al.'s (2002) claim that loneliness leads to depression (psychological impact) was found to be applicable only for women. Similarly, Booth (1972) advocated that women are more emotionally connected in a social network while men are more formal. Social control theory (Travis, 1969) advocated the influence of the network, namely, that friends and relatives encourage healthy behaviors and refrain people from adopting unhealthy behaviors. To summarize: H1 was supported for women only in the categories studied, implying that CAVSD has a differential or no PI for different groups.

As for $\mathrm{H} 2$, we found the results applied to the full sample as well as the individual categories, with similar effect sizes for both sexes. For the full sample, this study found that PI was a significant predictor of SNS usage intensity (H2). We also established a link between PI and SNS usage intensity in both men and women. Social distancing caused economical and psychological damage that results in social disconnectedness. According to Faris (2020), quarantine enhanced psychological anxiety and isolation and led to depression. Regarding 
$\mathrm{H} 2$, we found statistically significant results only for the 21-35 years old group. The psychological impact on this group was greatest. This young adult group was more likely to be worried about being away from the workplace, family, and isolated from friends and because they showed a statistically significant relationship between CAVSD and SNS usage intensity mediated by PI. Thus, we had evidence that PI affected SNS usage intensity in the 21-35 years old group. Hill (2020) reported that older people who are more prone to the risk of infection during a pandemic had lower conformity to social distancing. Considering our $\mathrm{H} 2$, that is, the impact of PI on SNS intensity for work status, we found a statistically significant effect for each category, although the effects sizes for the NWFH group were much higher than for the other two groups (WFH and SLO). Another study revealed a positive correlation between an individual's psychological depression and the amount of time he/she engaged in social networking (Pantic et al., 2012). Studies found that students who had depressive symptoms engaged in SNS more than those who were without psychological symptoms (Campbell et al., 2006; Morrison and Gore, 2010). One study found that online chatting was perceived by SNS users to be of assistance to cope with social fearfulness (Campbell et al., 2006). Some researchers also argued that there are therapeutic benefits of the usage of SNS (LaRose et al., 2001). To this effect, Hamman (1999) asserted that ethnographic research found that on-line interaction supplemented physical real-world relationships. Thus, we claimed that the PI of social distancing leads to social networking intensity in the full sample, in both sexes, all work statuses, but not in the age group 21-35 years old during a pandemic.

In the context of the third hypothesis (H3) we found CAVSD positively impacted SNS intensity in the full sample and had similar effect sizes for both sexes. The results of the tests for $\mathrm{H} 3$ also showed that CAVSD had a significant effect on SNS usage intensity only for the youngest age group, with an effect size that was much larger than for the other age groups. CAVSD was also a significant predictor of SNS usage intensity (H3). Our third hypothesis, how CAVSD impacts SNS usage intensity yielded statistically significant results for the SLO group alone. To summarize, the SLO group showed results similar to the full sample in terms of effect sizes and significance, while WFH and NWFH showed support only for H2. This study found that the PI of social distancing impacted social networking intensity. Social networks have been referred to as a world of connectivity (Turkle, 2017) and during periods of social distancing people want to be connected virtually through social media. In a similar line, one study found that updating statuses on SNS reduced loneliness and that individuals felt less lonely when they participated in social networking through social media (Deters and Mehl, 2013). When physical proximity is not possible, computer-mediated communication helps to maintain and solidify relationships (Ellison et al., 2007). Self-disclosure behavior on SNSs in the form of sharing and updating impacts psychological health (Lee et al., 2011). This study asserts that social distancing distress is reduced by increased social media engagement. Social networking in this study replaced physical proximity. Due to social distancing, people experienced a form of social disconnectedness. Social distancing creates a feeling of social disconnectedness, which is a subjective experience when people feel scarcity in terms of companionship and thereby SNS usage intensity increases. This was statistically significant in the SLO group, as students who were studying online had to be on social network platforms for their classes, to attend webinars, stay in touch with their friends, and to stay connected. People working from home (WFH) were more engaged in their official work platforms than those who were staying at home but not working (NWFH).

The present study was a countrywide study in India where there was social distancing and lockdown at a country level during the COVID-19 pandemic, as in other countries. Social 
networking platforms provided a means for social interaction. Thus, our study contributes to the social exchange model (Blau, 1964) in a virtual social network. Social networking during a pandemic-related lockdown paved the way for a personal cost-benefit analysis of human interaction as other alternatives were not available. The perceived benefit of social networking is higher than the cost of physical networking in a pandemic situation. Considering the above results for the full sample and the different subsets of the sample, we saw concentrations of the following groups driving the results: a) women, b) SLO and c) the 21-35 year old group. The hypotheses were also differently supported by the different groups of samples. Thus, it can be said that, although the boon of internet technologies and social media platforms were indeed the same for all, the usage and benefits reaped from these platforms were perceived differently by different individuals. Social networking is therefore different for different groups of people and led by push-pull factors (Lin et al. 2020) that still need to be studied.

\subsection{Theoretical contributions}

This study contributes to the existing literature by positing social networking as a basic virtual need for socialization and that social media platforms assist in that. Cognitive appraisal is an important determinant of individual response (Roesch et al., 2005) and leads to health outcomes (O'Connor et al., 2010). During periods of social distancing, people's need for physical socialization is not met and results in PI. The results also indicate that the PI of social distancing increased SNS usage intensity that may be critical to combat extreme levels of uncertainty and complexity during a pandemic (Yoo et al., 2016; Kim et al., 2018).The results of the study validate the theory of new-generation virtual needs, which states the major motivation for people to social networking is the need to retain citizenship in the virtual society (Krishen et al., 2016).

The results of the study also contribute to the theories of psychological coping. To alleviate the psychological impact of social distancing during a pandemic (Montemurro, 2020; Pakpour and Griffiths, 2020) social networking and internet usage have been identified as coping responses to psychological problems (Bernardi and Pallanti, 2009; Morrison and Gore, 2010).

This study also contributes to the literature of cognitive dissonance as it is linked to internet use (Jeong et al., 2019). As social animals, people favor social gatherings and social proximity, so supporting social distancing when faced with a health threat creates cognitive dissonance. In light of cognitive dissonance, CAVSD can be stressful and this stress expresses itself in the form of PI. Thus, a discrepancy in social proximity intention and the adoption of social distancing is psychologically impactful. People respond to this stress by adopting coping strategies for social networking.

This study has been able to link the PI of social distancing with social networking and show how effectively social media platforms and social networking can be used during a crisis for positive activities such as learning, creating awareness, and information dissemination (Kim et al., 2018; Manika et al., 2017; Martin et al., 2020; Qiao et al., 2019). On a learning and development level, social networking enhances learning (Valdez et al., 2020), moreover, during the COVID-19 pandemic SNSs also offered free training and certification courses and webinars. Social networking contributed by offering virtual audiences an opportunity to learn and acquire knowledge and skills in their areas of interest at their own pace. 
Increased social networking during social distancing impacts well-being and reduces depression (Chopik, 2016), and online games can have a positive effect on users' mood (Hassan et al., 2019). From a social-psychology perspective, forced physical isolation increases virtual social bonding by helping people to stay connected. No longer busy in selforientated "normal" life, people reach out to friends and relatives, and engage in more calls, chats, video meetings, daily live videos, hash-tag challenges, and so on. Our analysis also points out that these impacts are not uniform across all groups but may vary based on sex, age, and work status. Thus, we are able to contribute to an understanding of the role of individual versus group differences in the impact of CAVSD and PI and SNS usage intensity.

\subsection{Implications for practice}

The findings of this study are significant for organizations, corporate, educational, public, or private sectors. There is a need to identify that subsection of employees or students who might need social support and relief from isolation and loneliness. The counseling function within an organization needs to take into account that the increased intensity of SNS usage may stem from the psychological impact of isolation due to social distancing or other reasons. Thus, when conditions go back to normal, cyber "loafing" and other dysfunctional behavior resulting from increased SNS usage intensity need to be seen in context by respective managements. Even this may manifest as "phubbing" (ignoring others to play on a devise) behavior in meetings or classrooms. These need to be handled at an individual level, taking into account the cognitive appraisal made by the individual. This implies that the HR function has to focus on the individual characteristics of the employee rather than treat them as a group of employees. This might require an added emphasis on psychometric testing and understanding individuals' psychological makeup.

Our results demonstrate that the nature of the impact of CAVSD and PI on SNS usage intensity depends on the category that the employee may fall into. Thus, the results of the study have important implications for employers who have a large proportion of female employees and or younger employees in their ranks. The SNS usage intensity of these groups is impacted more by the CAVSD and PI than men or older employees, implying again that counseling and other employee engagement activities be tailored for these groups. The results of the study have an important implication for the educational sector as well. The future of education involves a substantial portion of online education, irrespective of when normal times return. Our results show that students learning online from home were also impacted in terms of SNS usage intensity by the CAVSD and PI and may exhibit the same behavior on campus. Educators will be required to take this into account in setting campus policies for SNS use.

Mental health experts advise curbing the unhindered consumption of news related to the pandemic (infodemic). The government has a critical role to play to ensure that transparent channels of information from the administration feed citizens with the required information to help reduce fear. When citizens have adequate, authentic information they will act rationally. When individuals are made aware of the measures they need to take during a crisis, it will help them psychologically to tackle fear.

Business organizations should focus on employee engagement programs to help beat COVID-19 stress. Corporations should find ways to stimulate their employees working from remote locations to stay motivated and thereby continue to contribute productively as many of them may be struggling with the emotional aftermath of the COVID-19 pandemic. Organizations must take up initiatives to help employees to cope up with the psychological 
turmoil that many may experience. Communication with employees from the organization's leadership team on a continual basis can create a sense of belonging and uplift employees' self-esteem and engagement.

Employees who are required to work remotely tend to miss the group interactions in an office environment and may at times start to feeling excluded (Brooks et al., 2020; Ter Hoeven and van Zoonen, 2020). Forming and maintaining social contact in virtual platforms can help in building team spirit. The problem of exclusion is particularly true for those employees who are working remotely for the first time. This virtual distance can lead to a growing sense of detachment when individuals tend to rely on technology rather than human interaction.

Companies that operate in India may utilize this situation as an opportunity to calibrate their employees to acclimatize to a "new normal" system of working in a void without customers or other employees. This period of unpredictability can generate prospects that organizations can leverage if they are equipped. In a pandemic, business organizations need to take firm decisions from a strategic perspective. The COVID-19 pandemic and the resultant lockdown have taken a toll on the mental health of scores of people working from home. With fear and anxiety about economic uncertainty on one side and family issues on the other, individuals working from home are undergoing mental stress and a range of behavioral issues. Psychologists also warn that a sudden feeling of isolation can lead to a host of behavioral and emotional issues including depression, agitation, anger, and loneliness. Companies could make extensive use their virtual social medium to conduct employee outreach programs to connect with their employees.

\section{Conclusion, limitations, and scope for future research}

Our study focused on exploring the effects of CAVSD and related PI and SNS usage intensity. The research was restricted to people who had access to the internet and who were conversant with Google forms and English. Future research may accentuate those social media users who may have less distress compared with non-social media users. The study was conducted to investigate the impact of CAVSD on SNS usage intensity and may be further extended to investigate other behavioral changes such as frequency of watching Netflix or TV. The pandemic has seen a major trade-off between the value of life, the psychological impact of isolation, and the economies of countries. India took the decision to save human lives over the economy by following the WHO protocol of a complete lockdown; that said, the ill effects of social distancing are visible in countries in terms of social unrest and psychological distress. The results of this study highlight that CAVSD have PI, but the effect size varies in groups categorized by sex, age and work status. The findings also highlight the effect of CAVSD and PI on SNS usage intensity and that it varies in the groups categorized by sex, age and work status.

Some important limitations of the study should be noted. Since the study was carried out on Indian respondents, the generalizability of the results is limited to countries with similar characteristics as India in terms of internet penetration, SNS usage, and regulatory regimes during the lockdown. This, however, provides an opportunity for researchers to replicate the study in other environments to see if similar results hold. Further, we were compelled to use a limited snowball sampling technique due to the constraints of the research methodology. A more extensive sample could be used to provide better statistical validity for the results. It should also be noted that our subgroups may not represent the population of SNS users as a whole. This may lead to limitations in the applicability of the results. 
Future research could focus on other subgroups such as nationality, education, job categories (including the essential services workers), social status, and socio-economic status. While this study provides novel evidence on the impact of CAVSD and PI on SNS usage intensity, it also opens up the field for further research that considers various factors that make up the cognitive appraisal and various behaviors that manifest PI. Thus, we feel that this study makes an important contribution in the field of human behavior and internet usage among different groups of people during a pandemic outbreak.

\section{References}

Adolph, C., Amano, K., Bang-Jensen, B., Fullman, N., and Wilkerson, J. (2021), "Pandemic politics: Timing state-level social distancing responses to COVID-19", Journal of Health Politics, Policy and Law, doi: doi:10.1001/jamapediatrics.2020.3610

Afe, T. O., andOgunsemi, O. (2016), "Social distancing attitudes toward the mentally ill and victims of sexual violence among college students in Southwest Nigeria", Indian Journal of Social Psychiatry, Vol. 32 No. 4, pp. 320-324.

Ajmal, A. (2020), "Covid-19: Practice information hygiene to deal with misinformation, say experts: India News Ahmedabad Mirror. available at:https://ahmedabadmirror.indiatimes.com/news/india/covid-19-practice-informationhygiene-to-deal-with-misinformation-say-experts/articleshow/75073137.cms (accessed 12 April 2020)

Alalwan, A. A., Dwivedi, Y. K., and Rana, N. P. (2017), "Factors influencing adoption of mobile banking by Jordanian bank customers: Extending UTAUT2 with trust," International Journal of Information Management, Vol. 37 No. 3, pp. 99-110.

Alhurani, A. S., Dekker, R., Ahmad, M., Miller, J., Yousef, K. M., Abdulqader, B., Salami, I., Lennie, T.A., Randall, D.C. and Moser, D. K. (2018), "Stress, cognitive appraisal, coping, and event free survival in patients with heart failure", Heart Lung, Vol. 47 No. 3, pp. 205-210.

Andersen, M. (2020), "Early Evidence on Social Distancing in Response to COVID-19 in the United States", available at:

https://Papers.ssrn.com/sol3/Papers.cfm?abstract_id=3569368, http://dx.doi.org/10.2139/ssrn.3569368 (accessed 2 May 2020)

Aravind, I. (2020), "Covid-19: Why social distancing is a big worry for senior citizens", available at: https://economictimes.indiatimes.com/news/politics-and-nation/covid-19why-social-distancing-is-a-big-worry-for-senior-citizens/articleshow/74866566.cms (accessed 10 April 2020)

Arora, A., Bansal, S., Kandpal, C., Aswani, R., andDwivedi, Y. (2019), "Measuring social media influencer index-insights from Facebook, Twitter and Instagram”, Journal of Retailing and Consumer Services, Vol. 49, pp. 86-101.

Atwater, L., andCarmeli, A. (2009), "Leader-member exchange, feelings of energy, and involvement in creative work", The Leadership Quarterly, Vol. 20 No. 3, pp. 264-275.

Azodo, C. C., andOgbebor, O. G. (2019), "Social distance towards halitosis sufferers", Swiss Dental Journal, Vol. 129 No. 12, pp. 1026-1030. 
Balram, S. (2020), "Covid-19 Impact: Social media activity in the country grew 50X in early March, says Nielsen”, available

at:https://economictimes.indiatimes.com/tech/internet/covid-19-impact-social-mediaactivity-in-the-country-grew-50x-in-early-march-says-nielsen/articleshow/74833596.cms (accessed 11 April 2020)

Banerjee, C. (2020), "Interest booms in doomsday material - Times of India", available at: https://timesofindia.indiatimes.com/india/interest-booms-in-doomsdaymaterial/articleshow/74819955.cms (accessed 12 April 2020)

Barnes, S. J. (2020), "Information management research and practice in the post-COVID-19 world”, International Journal of Information Management, Vol. 55, p. 102175.

Barrett, P. (2007), "Structural equation modelling: Adjudging model fit", Personality and Individual Differences, Vol. 42 No. 5, pp. 815-824.

Benson, V., Hand, C., and Hartshorne, R. (2019), "How compulsive use of social media affects performance: insights from the UK by purpose of use", Behaviour\& Information Technology, Vol. 38 No. 6, pp. 549-563.

Bernardi, S., andPallanti, S. (2009), "Internet addiction: a descriptive clinical study focusing on comorbidities and dissociative symptoms", Comprehensive Psychiatry, Vol. 50No. 6, pp. 510-516.

Bhimani, H., Mention, A.L., and Barlatier, P.-J. (2019), "Social media and innovation: A systematic literature review and future research directions", Technological Forecasting and Social Change, Vol.144, pp. 251-269.

Blau, P. M. (1964), Exchange and Power in Social Life. New York, NY: John Wiley and Sons.

Booth, A. (1972), "Sex and social participation", American Sociological Review, Vol 37 No. 3 pp. 183-193.

Boyd, D. M., and Ellison, N. B. (2007), "Social network sites: Definition, history, and scholarship", Journal of Computer-Mediated Communication, Vol. 13 No.1, pp. 210-230.

Brody, L. R., and Hall, J. A. (2008), "Gender and emotion in context”, Handbook of Emotions, Vol. 3, pp. 395-408

Brooks, S. K., Webster, R. K., Smith, L. E., Woodland, L., Wessely, S., Greenberg, N., and Rubin, G. J. (2020), "The psychological impact of quarantine and how to reduce it: rapid review of the evidence", The Lancet, Vol. 395 No. 10227, pp. 912-920.

Cacioppo, J. T., Hawkley, L. C., Norman, G. J., andBerntson, G. G. (2011), "Social isolation", Annals of the New York Academy of Sciences, Vol. 1231 No. 1, pp. 17.

Campbell, A. J., Cumming, S. R., and Hughes, I. (2006), Internet use by the socially fearful: Addiction or therapy? Cyber Psychology\& Behavior, Vol. 9 No.1, pp. 69-81. 
Cao, W., Fang, Z., Hou, G., Han, M., Xu, X., Dong, J., andZheng, J. (2020), "The psychological impact of the COVID-19 epidemic on college students in China", Psychiatry Research, 112934.https://doi.org/10.1016/j.psychres.2020.112934

Cao, X., Gong, M., Yu, L. andDai, B. (2020), "Exploring the mechanism of social media addiction: an empirical study from WeChat users", Internet Research, Vol. 30 No. 4, pp. 1305-1328. https://doi.org/10.1108/INTR-08-2019-0347

Carpenter, C. J. (2019), "Cognitive dissonance, ego-involvement, and motivated reasoning”,Annals of the International Communication Association, Vol. 43 No. 1, pp. 123.

Chakraborty, T. (2020), "Nothing to Condemn, Control and Criticize: The Bright Side of Work from Home during COVID-19 Pandemic", available at: https://www.rsb.edu.in/blog/nothing-to-condemn-control-and-criticize-the-bright-side-ofwork-from-home-during-covid-19-pandemic/ (accessed 12 May, 2020)

Chen, F. H. (2009), "Modeling the effect of information quality on risk behavior change and the transmission of infectious diseases", Mathematical Biosciences, Vol. 217 No. 2, pp. 125-133.

Cheng, X., Fu, S., and de Vreede, G. J. (2017), "Understanding trust influencing factors in social media communication: A qualitative study”, International Journal of Information Management, Vol. 37 No. 2, pp. 25-35.

Choi, S. (2019), "The roles of media capabilities of smartphone-based SNS in developing social capital",Behaviour\& Information Technology, Vol. 38 No. 6, pp. 609-620.

Chopik, W. J. (2016), “The benefits of social technology use among older adults are mediated by reduced loneliness", cyber psychology, Behavior\& Social Networking, Vol. 19 No. 9, pp. 551-556.

Cioffi, C. E., Levitsky, D. A., Pacanowski, C. R., and Bertz, F. (2015), “A nudge in a healthy direction. The effect of nutrition labels on food purchasing behaviors in university dining facilities", Appetite, Vol. 92, pp. 7-14.

Cocosila, M., and Turel, O. (2019), "Adoption and non-adoption motivational risk beliefs in the use of mobile services for health promotion", Internet Research. Vol. 29 No. 4, pp. 846-869.

Cohen, S., and Wills, T. A. (1985), "Stress, social support, and the buffering hypothesis", Psychological Bulletin, Vol. 98, pp. 310-357.

Cooper, J. (2012), "Cognitive dissonance theory", In P. A. M. Lange, A. W. Kruglanski, and E. T. Higgins (Eds.), Handbook of theories of social psychology, pp. 377-397. Thousand Oaks, CA: Sage.

De, R., Pandey, N. and Pal, A. (2020), "Impact of Digital Surge during Covid-19 Pandemic: A Viewpoint on Research and Practice",International Journal of Information Management, Vol. 55, p. 102171. 
De Choudhury, M., Gamon, M., Counts, S., and Horvitz, E. (2013), "Systems”, April 2013. pp. 3267-3276.

De Zwart, O., Veldhuijzen, I. K., Elam, G., Aro, A. R., Abraham, T., Bishop, G. D., and Brug, J. (2007), “Avian influenza risk perception, Europe and Asia”, Emerging Infectious Diseases, Vol. 13 No. 2, pp. 290.

Deters, F. G., and Mehl, M. R. (2013), "Does posting Facebook status updates increase or decrease loneliness? An online social networking experiment", Social Psychological and Personality Science, Vol. 4 No. 5, pp. 579-586.

DeWall, C. N., and Baumeister, R. F. (2006), "Alone but feeling no pain: Effects of social exclusion on physical pain tolerance and pain threshold, affective forecasting, and interpersonal empathy", Journal of Personality and Social Psychology, Vol. 91, pp. 115.

Dolgin, R., and Fazel, F. (2020), "How to Survive Social Distancing", available at: https://www.psycom.net/coronavirus-social-distancing-mental-health/ (accessed 11 April 2020)

Dou, M., Gu, Y., and Xu, G. (2020),"Social awareness of crisis events: A new perspective from social-physical network”,Cities, Vol. 99, p. 102620.

Dwivedi, Y. K., Kelly, G., Janssen, M., Rana, N. P., Slade, E. L., and Clement, M. (2018), "Social Media: The good, the bad, and the ugly", Information Systems Frontiers, Vol. 20 No. 3, pp. 419-423.

Dwivedi, Y.K., Hughes, D.L., Coombs, C., Constantiou, I., Duan, Y., Edwards, J.S., Gupta, B., Lal, B., Misra, S., Prashant, P. and Raman, R. (2020), "Impact of COVID-19 pandemic on information management research and practice: Transforming education, work and life", International Journal of Information Management, Vol. 55, p.102211.

Eid, M. I., and Al-Jabri, I. M. (2016), "Social networking, knowledge sharing, and student learning: The case of university students", Computers \& Education, Vol. 99, pp. 14-27.

Ellison, N. B., Steinfield, C., and Lampe, C. (2007), "The benefits of Facebook "friends:" Social capital and college students' use of online social network sites", Journal of Computer-Mediated Communication, Vol. 12 No. 4, pp. 1143-1168.

Falke, A., Schröder, N., and Endres, H. (2020), "A first fit index on estimation accuracy in structural equation models", Journal of Business Economics, Vol. 90 No. 2, pp. 277-302.

Fallows, D. (2005). How women and men use the Internet. Pew Internet \& American Life Project, Vol. 28, pp 1-45. available at:

https://www.pewresearch.org/internet/2005/12/28/how-women-and-men-use-the-internet/ (accessed 21 May 2020)

Faris, D. (2020),“Coronavirus' Looming Psychological Crisis”, The Week, 19 March 2020, available at: https://theweek.com/articles/903343/coronavirus-looming-psychologicalcrisis (accessed 20 March 2020) 
Ferguson, N. M., Laydon, D., Nedjati-Gilani, G., Imai, N., Ainslie, K., Baguelin, M., Bhatia, S., Boonyasiri, A., Cucunuba Perez, Z.U.L.M.A., Cuomo-Dannenburg, G. and Dighe, A., (2020), Report 9: Impact of non-pharmaceutical interventions (NPIs) to reduce COVID19 mortality and healthcare demand. Imperial College London; 16 March 2020, available at https://doi. org/10.25561/77482.

Festinger, L. (1957), A theory of cognitive dissonance. Evanston, IL: Row, Peterson.

Fong, M. W., Gao, H., Wong, J. Y., Xiao, J., Shiu, E. Y., Ryu, S., and Cowling, B. J. (2020), "Nonpharmaceutical Measures for Pandemic Influenza in Nonhealthcare Settings-Social Distancing Measures”, Emerging Infectious Diseases, Vol. 26 No. 5,pp. 976

Fritscher, L. (2020), "How to Know If You Have Cabin Fever or Fear of Isolation", available at: https://www.verywellmind.com/cabin-fever-fear-of-isolation-2671734 (accessed 8 April 2020)

Graham, A., Toon, I., Wynn-Williams, K., and Beatson, N. (2017), 'Using 'nudges' to encourage student engagement: an exploratory study from the UK and New Zealand", The International Journal of Management Education, Vol. 15 No. 2, pp. 36-46.

Gurnani, S. (2020), "Social Distance, Physical Distance and Imposed Quarantine", available at:https://iibp.org.in/social-distance-physical-distance-and-imposed-quarantine/ (accessed 10 April 2020)

Guynn, J. (2020), "Facebook and COVID19: They deleted the app, said goodbye to friends", Then came coronavirus", available at:https://www.usatoday.com/story/tech/2020/04/03/coronavirus-facebook-COVID19social-distancing-connection/5117765002/ (accessed 11 April 2020)

Hamman, R. B. (1999), "Computer networks linking network communities: Effects of AOL use upon pre-existing communities", available athttp://www.socio.demon.co.uk/cybersociety/ (accessed 10 April 10 2020)

Han, S., Min, J., and Lee, H. (2015), “Antecedents of social presence and gratification of social connection needs in SNS: A study of Twitter users and their mobile and nonmobile usage", International Journal of Information Management, Vol. 35 No. 4, pp. 459-471.

Hargittai, Eszter. (2008), "Whose space? Differences among users and non-users of social network sites", Journal of Computer-Mediated Communication, Vol.13, pp. 276-297.

Hassan, L., Dias, A., and Hamari, J. (2019), “How motivational feedback increases user's benefits and continued use: A study on gamification, quantified-self and social networking "International Journal of Information Management, Vol. 46, pp. 151-162.

Hawi, N., and Samaha, M. (2019), "Identifying commonalities and differences in personality characteristics of Internet and social media addiction profiles: traits, self-esteem, and self-construal”, Behaviour\& Information Technology, Vol.38 No.2, pp.110-119.

Hernández-Ortega, B. (2018), “Don’t believe strangers: Online consumer reviews and the role of social psychological distance", Information \& Management, Vol. 55 No. 1, pp. 31-50. 
Herring, S. C. (1993), "Gender and democracy in computer-mediated communication. Electronic Journal of Communication", Vol 3 No.2, available at:https://ella.sice.indiana.edu/ herring/ejc.txthttps://doi.org/10.1016/b978-0-12-4150409.50121-4 (accessed on 13 April 2020)

Hewett, R., Liefooghe, A., Visockaite, G., and Roongrerngsuke, S. (2018), "Bullying at work: Cognitive appraisal of negative acts, coping, wellbeing, and performance", Journal of Occupational Health Psychology, Vol. 23 No. 1, pp. 71-84.

Hill, A. (2020), "UK Families Meet up before Expected Lockdown for over-70s", The Guardian, available at:https://www.theguardian.com/world/2020/mar/17/uk-familiesmeetup-before-expected-lockdown-for-over-70s (accessed 18 March 2020)

Hinojosa, A. S., Gardner, W. L., Walker, H. J., Cogliser, C., and Gullifor, D. (2016), “A Review of Cognitive Dissonance Theory in Management Research", Journal of Management, Vol. 43 No.1, pp. 170-199.

Ho, C. S., Chee, C. Y., and Ho, R. C. (2020), "Mental health strategies to combat the psychological impact of COVID-19 beyond paranoia and panic", Annals of the Academy of Medicine, Singapore, Vol. 49 No. 1, pp. 1-3.

Hogeboom, D. L., McDermott, R. J., Perrin, K. M., Osman, H., and Bell-Ellison, B. A. (2010), "Internet use and social networking among middle aged and older adults”, Educational Gerontology, Vol. 36No.2, pp. 93-111.

Holshue, M. L., DeBolt, C., Lindquist, S., Lofy, K. H., Wiesman, J., Bruce, HSpitters, C., Ericson, K., Wilkerson, S., Tural, A. and Diaz, G. (2020), "First Case of 2019 Novel Coronavirus in the United States", New England Journal of Medicine, Vol. 382, pp. 929936.

Hoof, E. V. (2020), "Lockdown is the world's biggest psychological experiment - and we will pay the price", available at:https://www.weforum.org/agenda/2020/04/this-is-thepsychological-side-of-the-covid-19-pandemic-that-were-ignoring/ (accessed 13 April 13 2020)

Huang, J. Z., Han, M. F., Luo, T. D., Ren, A. K., and Zhou, X. P. (2020), "Mental health survey of 230 medical staff in a tertiary infectious disease hospital for COVID-19", Zhonghualao dong wei sheng zhi ye bingzazhi= Zhonghualaodongweishengzhiyebingzazhi $=$ Chinese Journal of Industrial Hygiene and Occupational Diseases, Vol. 38, E001.

Hughes, M. E., Waite, L. J., Hawkley, L. C., and Cacioppo, J. T. (2004), “A short scale for measuring loneliness in large surveys: Results from two population-based studies", Research on Aging, Vol. 26 No. 6, pp. 655-672.

Jeong, M., Zo, H., Lee, C. H., andCeran, Y. (2019), "Feeling displeasure from online social media postings: A study using cognitive dissonance theory", Computers in Human Behavior, Vol. 97, pp. 231-240.

Jost, J. T., Barberá, P., Bonneau, R., Langer, M., Metzger, M., Nagler, J., Sterling, J Tucker, J. A. (2018), "How social media facilitates political protest: Information, motivation, and social networks",Political Psychology, Vol. 39, pp. 85-118. 
Kallbekken, S., and Sælen, H. (2013), "Nudging hotel guests to reduce food waste as a winwin environmental measure", Economics Letters, Vol. 119 No. 3, pp. 325-327.

Kaplan, S., Grünwald, L., andHirte, G. (2016), “The effect of social networks and norms on the inter-regional migration intentions of knowledge-workers: The case of Saxony, Germany", Cities, 55, pp. 61-

69.https://doi.org/https://doi.org/10.1016/j.cities.2016.03.017

Katz, J. E. andAspden, P. (1997), “A nation of strangers?”, Communications of the ACM, Vol. 40 No. 12, pp. 81-86.

Kim, J., Bae, J., andHastak, M. (2018), "Emergency information diffusion on online social media during storm Cindy in U.S", International Journal of Information Management, Vol. 40, pp.153-165.

Kimbrough, A. M., Guadagno, R. E., Muscanell, N. L., and Dill, J. (2013), “Gender differences in mediated communication: Women connect more than do men", Computers in Human Behavior, Vol. 29 No.3, pp. 896-900.

Koo, J. R., Cook, A. R., Park, M., Sun, Y., Sun, H., Lim, J. T. Tam, C. and Dickens, B.L., (2020), "Interventions to mitigate early spread of SARS-CoV-2 in Singapore: a modelling study", The Lancet Infectious Diseases, available at:https://www.thelancet.com/journals/laninf/article/PIIS1473-3099(20)301626/fulltexthttps://doi.org/10.1016/s1473-3099(20)30162-6 (accessed 18 April 2020)

Kraut, R., Patterson, M., Lundmark, V., Kiesler, S., Mukhopadhyay, T., andScherlis, W. (1998), "Internet paradox: A social technology that reduces social involvement and psychological well-being?", American Psychologist, Vol. 53 No. 9, pp.1017-1031.

Krishen, A. S., Berezan, O., Agarwal, S., andKachroo, P. (2016), "The generation of virtual needs: Recipes for satisfaction in social media networking", Journal of Business Research, Vol. 69 No. 11, pp. 5248-5254.

Lai, H. M., Hsieh, P. J., and Zhang, R. C. (2019), “Understanding adolescent students' use of Facebook and their subjective wellbeing: a gender-based comparison",Behaviour\& Information Technology, Vol. 38 No. 5, pp. 533-548.

LaRose, R., Eastin, M. S., and Gregg, J. (2001), "Reformulating the Internet paradox: Social cognitive explanations of Internet use and depression", Journal of Online Behavior, Vol. 1 No. 2, pp. 1092-4790.

Lee, Y. (2020), "Motivations of employees' communicative behaviors on social media", Internet Research. Vol. 30 No. 3, pp. 971-994.

Lee, G., Lee, J., and Kwon, S. (2011), "Use of social-networking sites and subjective wellbeing: A study in South Korea", cyber psychology, Behavior \& Social Networking, Vol. 14 No.3, pp. 151-155.

Leonardi, P. M. (2018), "Social media and the development of shared cognition: The roles of network expansion, content integration, and triggered recalling",Organization Science, Vol. 29 No.4, 547-568. 
Lewnard, J. A., and Lo, N. C. (2020), "Scientific and ethical basis for social-distancing interventions against COVID-19", The Lancet. Infectious diseases. available at:https://www.thelancet.com/journals/lancet/article/PIIS1473-3099(20) 30190-0/full text (accessed 10 April 2020)

Li, Q., Zhao, L., Xue, Y., and Feng, L. (2020), “Stress-buffering pattern of positive events on adolescents: An exploratory study based on social networks",Computers in Human Behavior, Vol. 0, pp.106565. https://doi.org/https://doi.org/10.1016/j.chb.2020.106565

Li, X., Xu, G., Jiao, L., Zhou, Y., and Yu, W. (2019), "Multi-layer network community detection model based on attributes and social interaction intensity", Computers \& Electrical Engineering, Vol.77, pp.300-313.

Lin, C. F., Fu, C. S., and Chi, T. H. (2020), "Constructing a hybrid hierarchical value map to understand young people's perceptions of social networking sites", Behaviour\& Information Technology, Vol. 39 No. 2, pp.150-166.

Lipsman, A. (2006), "ComScore press release”, available at:https://www.comscore.com/Insights/Press-Releases (accessed 12 April 2020)

Liu, Z., and Wang, X. (2018),"How to regulate individuals' privacy boundaries on social network sites: A cross-cultural comparison",Information \& Management, Vol. 55 No. 8, pp. 1005-1023.

Lockerd Maragakis, L. (2020), "Coronavirus, Social and Physical Distancing and SelfQuarantine", available at:https://www.hopkinsmedicine.org/health/conditions-anddiseases/coronavirus/coronavirus-social-distancing-and-self-quarantine (accessed 12 April 2020)

Lundquist, A., andGurung, R. A. (2019), "Social Distancing Individuals with Depression: The Impact of Symptom Severity”, Psi Chi Journal of Psychological Research, Vol. 24 No. 3, pp. 159-165

MacKenzie, S. B., andPodsakoff, P. M. (2012), "Common method bias in marketing: Causes, mechanisms, and procedural remedies", Journal of Retailing, Vol. 88 No. 4, pp. 542555 .

Maharaj, S., andKleczkowski, A. (2012), "Controlling epidemic spread by social distancing: Do it well or not at all”, BMC Public Health, Vol.12 No.1, pp. 679-679.

Manika, D., Papagiannidis, S., andBourlakis, M. (2017), "Understanding the effects of a social media service failure apology: A comparative study of customers vs. potential customers", International Journal of Information Management, Vol. 37 No. 3, pp. 214 228.

Marcy, R. T. (2015), "Breaking mental models as a form of creative destruction: The role of leader cognition in radical social innovations", The Leadership Quarterly, Vol. 26No. 3, pp. 370-385.

Martin, N., Rice, J., and Arthur, D. (2020), “Advancing social media derived information messaging and management: A multi-mode development perspective", International Journal of Information Management, Vol. 51, pp. 102021. 
Matsuba, M. K. (2006), "Searching for self and relationships online", Cyber Psychology\& Behavior, Vol. 9, pp. 275-284.

Matthes, J., Karsay, K., Schmuck, D., andStevic, A. (2020), “Too much to handle”: Impact of mobile social networking sites on information overload, depressive symptoms, and wellbeing”, Computers in Human Behavior, Vol. 105, pp.106217.

McAlonan, G. M., Lee, A. M., Cheung, V., Cheung, C., Tsang, K. W., Sham, P. C Chua, S.Eand Wong, J. G. (2007), "Immediate and sustained psychological impact of an emerging infectious disease outbreak on health care workers", The Canadian Journal of Psychiatry, Vol. 52 No. 4, pp. 241-247.

Mehta, K. M., Yaffe, K., andCovinsky, K. E. (2002), "Cognitive impairment, depressive symptoms, and functional decline in older people", Journal of the American Geriatrics Society, Vol. 50 No. 6, pp. 1045-1050.

Menon, S. (2011), "Linking generativity and disruptive innovation to conceptualize ICTs", Internet Research.Vol.21No.3, pp.347-361.

Momsen, K., and Stoerk, T. (2014), "From intention to action: Can nudges help consumers to choose renewable energy?”, Energy Policy, Vol. 74, pp. 376-382

Montemurro, N. (2020), "The emotional impact of COVID-19: from medical staff to common people. Brain, Behavior, and Immunity", available at:https://www.unboundmedicine.com/medline/citation/32240766/The emotional_impact _of_COVID-19:_from_medical_staff_to_common_people (accessed 28 April 2020)

Morrison, C. M., and Gore, H. (2010), "The relationship between excessive Internet use and depression: a questionnaire-based study of 1,319 young people and adults”, Psychopathology, Vol. 43 No. 2, pp.121-126.

Nabity-Grover, T., Cheung, C. M., and Thatcher, J. B. (2020), "Inside out and outside in: How the COVID-19 pandemic affects self-disclosure on social media",International Journal of Information Management, Vol. 55, p. 102188.

Nielsen (2006), "Social networking sites grow 47 percent, year over year, reaching 45 percent of web users, according to Nielsen//Net Ratings", available at:http://www.nielsennetratings.com/pr/pr_060511.pdf (accessed 13 April 2020)

Nielsen (2009), “Global faces and networked places: A Nielsen report on social networking's new global footprint", available at:https://www.nielsen.com/wpcontent/uploads/sites/3/2019/04/Global-Faces-and-Networked-Places-A-Nielsen-Reporton-Social-Networkings-New-Global-Footprint.pdf (accessed 2 April 2020)

O’Connor, K. M., Arnold, J. A., and Maurizio, A. M. (2010), “The prospect of negotiating: Stress, cognitive appraisal, and performance", Journal of Experimental Social Psychology, Vol. 46 No. 5, pp. 729-735.

Oberski, D. (2014), "lavaan. survey: An R package for complex survey analysis of structural equation models", Journal of Statistical Software, Vol. 57 No. 1, pp. 1-27. 
O'Dair, B., and Fazel, F. (2020), "Coronavirus Worries Keeping You Up? Coronavirus Anxiety-Related Insomnia?”, available at:https://www.psycom.net/coronavirus-insomnia (accessed 11 April 2020)

Pakpour, A. H., and Griffiths, M. D. (2020), "The fear of CoVId-19 and its role in preventive behaviors", Journal of Concurrent Disorders, Vol. 2 No. 1, pp. 58-63.

Pantic, I., Damjanovic, A., Todorovic, J., Topalovic, D., Bojovic-Jovic, D., Ristic, S., and Pantic, S. (2012), "Association between online social networking and depression in high school students: behavioral physiology viewpoint", PsychiatriaDanubina, Vol. 24 No.1, pp. 90-93.

Parikh, S. P., Desai, M., and Parikh, R. (2020), "Covid-19 in the times of Social media", at:https://www.indiatoday.in/mail-today/story/covid-19-in-the-times-of-social-media1666109-2020-04-12 (accessed 13 April 2020)

Pew Research. (2010), "Older adults and social media", available at: http://www.pewinternet.org/ /media//Files/Reports/2010/Pew\%20Internet\%20$\% 20$ Older\%20Adults\%20and\%20Social\%20Media.pdf (accessed 20 October 2010)

Phu, B., and Gow, A. J. (2019), "Facebook use and its association with subjective happiness and loneliness", Computers in Human Behavior, 92, pp.151-159.

Podsakoff, P. M., MacKenzie, S. B., Lee, J. Y., and Podsakoff, N. P. (2003), "Common method biases in behavioral research: a critical review of the literature and recommended remedies", Journal of Applied Psychology, Vol. 88 No. 5, pp. 879.

Ponnusamy, S., Iranmanesh, M., Foroughi, B., and Hyun, S. S. (2020), "Drivers and outcomes of Instagram Addiction: Psychological well-being as moderator", Computers in Human Behavior, Vol. 107, pp. 106294.

Putnam, R. (1995), "Bowling alone: America's declining social capital”, Journal of Democracy, Vol. 6, pp.65-78.

Qiao, T., Shan, W., Zhang, M., and Liu, C. (2019), "How to facilitate knowledge diffusion in complex networks: The roles of network structure, knowledge role distribution and selection rule", International Journal of Information Management, Vol.47, pp.152-167.

Qualls, N., Levitt, A., Kanade, N., Wright-Jegede, N., Dopson, S., Biggerstaff, M., and Levitt, A. (2017), "Community mitigation guidelines to prevent pandemic influenzaUnited States, 2017”, MMWR Recommendations and Reports, Vol.66 No.1, pp.1-34.

Ramasubramanian, S., Doshi, M. J., and Saleem, M. (2017), "Mainstream versus ethnic media: How they shape ethnic pride and self-esteem among ethnic minority audiences", International Journal of Communication, Vol. 11 No. 21, pp.1879-1899.

Reluga, T. C. (2010), "Game theory of social distancing in response to an epidemic", PLoS Computational Biology, Vol. 6, No. 5, pp. e1000793.

Reluga, T. C., Bauch, C. T., and Galvani, A. P. (2006), "Evolving public perceptions and stability in vaccine uptake”, Mathematical Biosciences, Vol. 204 No. 2, pp.185-198. 
Roberts, D. F., Foehr, U. G., and Rideout, V. (2005), "Generation M: Media in the lives of 818 year-olds. Menlo Park, CA: Kaiser Family Foundation. Washington, DC", available at:https://www.kff.org/other/event/generation-m-media-in-the-lives-of/ (accessed 17 April 2020)

Robinson, S.(2020), "Coronavirus Self-Isolation: A Psychologist Explains How To Avoid Cabin Fever", available at:https://theconversation.com/coronavirus-self-isolation-apsychologist-explains-how-to-avoid-cabin-fever-133317 (accessed 16 April 2020)

Roesch, S. C., Adams, L., Hines, A., Palmores, A., Vyas, P., Tran, C., and Vaughn, A. A. (2005), "Coping with prostate cancer: a meta-analytic review", Journal of Behavioral Medicine, Vol. 28 No. 3, pp. 281-293.

Roscoe, J. T., and Byars, J. A. (1971), "An investigation of the restraints with respect to sample size commonly imposed on the use of the chi-square statistic", Journal of the American Statistical Association, Vol.66 No. 336, pp. 755-759.

Rosseel, Y., Oberski, D., Byrnes, J., Vanbrabant, L., Savalei, V., Merkle, E., and Chow, M. (2017), Package 'lavaan'. available at:https://cran.rproject.org/web/packages/lavaan/lavaan.pdf (accessed 20 April 2020)

Rotondi, V., Stanca, L., and Tomasuolo, M. (2017), "Connecting alone: Smartphone use, quality of social interactions and well-being", Journal of Economic Psychology, Vol. 63, pp. 17-26.

Russell, D., Peplau, L. A., and Ferguson, M. L. (1978), "Developing a measure of loneliness”, Journal of Personality Assessment, Vol. 42 No. 3, pp. 290-294.

Seaton, V., and Piel, M. (2017), "Student pharmacists' social distancing toward people with mental illness", Mental Health Clinician, Vol. 7 No. 5, pp. 181-186.

Seitz D. (2019), "Yes, cabin fever is real-here's how to prevent it. Don't let winter isolation ruin your mood. Popular Science", available at:https://www.popsci.com/prevent-cabinfever/ (accessed 16 April 2020)

Sharma, S., Singh, G., Sharma, R., Jones, P., Kraus, S., and Dwivedi, Y. K. (2020), "Digital health innovation: exploring adoption of COVID-19 digital contact tracing apps",IEEE Transactions on Engineering Management, doi: 10.1109/TEM.2020.3019033.

Shelton, R. C., Lee, M., Brotzman, L. E., Crookes, D. M., Jandorf, L., Erwin, D., and GageBouchard, E. A. (2019), "Use of social network analysis in the development, dissemination, implementation, and sustainability of health behavior interventions for adults: A systematic review”, Social Science \& Medicine, Vol. 220, pp. 81-101.

Shen, X., and Wang, J. L. (2019), "Loneliness and excessive smartphone use among Chinese college students: Moderated mediation effect of perceived stressed and motivation", Computers in Human Behavior, Vol. 95, pp. 31-36

Shkoler, O., and Tziner, A. (2017), "The mediating and moderating role of burnout and emotional intelligence in the relationship between organizational justice and work misbehavior", Revista de Psicologia del Trabajo y de las Organizaciones, Vol. 33No. 2, pp. 157-164. 
Sideri, M., Kitsiou, A., Filippopoulou, A., Kalloniatis, C., and Gritzalis, S. (2019), "Egovernance in educational settings: Greek educational organizations leadership's perspectives towards social media usage for participatory decision-making", Internet Research, Vol. 29 No. 4, pp. 818-845.

Sproull, L. S., Kiesler, S., and Zubrow, D. (1984), "Encountering an alien culture”, Journal of Social Issues, Vol. 40No. 3, pp. 31-48.

Taylor, M. (2009), "Women outnumber men on social networking sites", The Wall Street Journal, available at http://blogs.wsj.com/digits/2009/10/07/women-outnumbermen-onsocial-networking-sites/

terHoeven, C. L., and van Zoonen, W. (2020), "Helping Others and Feeling Engaged in the Context of Workplace Flexibility: The Importance of Communication Control", International Journal of Business Communication, pp.2329488419898799, doi:https://doi.org/10.1177/2329488419898799

Thompson, S. H., and Lougheed, E. (2012), "Frazzled by Facebook? An exploratory study of gender differences in social network communication among undergraduate men and women”, College Student Journal, Vol. 46 No. 1, pp. 88-99.

Tokunaga, R. S. (2016), “Interpersonal surveillance over social network sites: Applying a theory of negative relational maintenance and the investment model", Journal of Social and Personal Relationships, Vol. 33 No.2, pp. 171-190.

Tolette, A. (2020), "How Coronavirus has Shifted the Way the World Works", available at https://www.synthesio.com/blog/how-coronavirus-has-shifted-the-way-the-world-works/

Travis, H. (1969), Causes of delinquency. Berkeley, CA: University of California.

Tsovaltzi, D., Dutta, N., Puhl, T., and Weinberger, A. (2017),“Group and Individual Level Effects of Supporting Socio-Cognitive Conflict Awareness and Its Resolution in Large SNS", Discussion Groups: A Social Network Analysis. Philadelphia, PA: International Society of the Learning Sciences.

Turkle, S. (2017), "Alone Together: Why we expect more from technology and less from each other", Basic Books, NY.

Upadhyay, P., and Kumar, A. (2020), "The intermediating role of organizational culture and internal analytical knowledge between the capability of big data analytics and a firm's performance", International Journal of Information Management, Vol. 52, pp. 102100.

Vaidis, D. C., and Bran, A. (2019),"Respectable challenges to respectable theory: cognitive dissonance theory requires conceptualization clarification and operational tools",Frontiers in Psychology, Vol. 10, pp. 1189.

Valdez, G. F. D., Cayaban, A. R., AL-Fayyadh, S., Korkmaz, M., Obeid, S., Sanchez, C. L. A., Ajzoon, M.B., Fouly, H. and Cruz, J.P. (2020), "A Multi-Country Perspectives on Social Networking Sites Utilization, Perceived Benefits \& Potential for Improving Study Habits among Nursing Students”, BMC Nursing, doi: 10.21203/rs.2.21565/v1. 
Valdez, L. D., Macri, P. A., and Braunstein, L. A. (2012), "Intermittent social distancing strategy for epidemic control”, Physical Review E, Vol. 85 No. 3, pp. 036108.

Vallgårda, S. (2012), "Nudge-A new and better way to improve health?”, Health Policy, Vol. 104 No. 2, pp. 200-203.

Verhaagen, D. (2005), "Parenting the millennium generation: guiding our children born between 1982 and 2000", Westport, CT: Prager Publishers.

Veroff, J., Douvan, E., and Kulka, R. A. (1981), "The inner American: A self-portrait from 1957 to 1976”, New York: Basic Books.

Virick, M., Basu, A., and Rogers, A. (2015), “Antecedents of entrepreneurial intention among laid-off individuals: A cognitive appraisal approach", Journal of Small Business Management, Vol. 53 No. 2, pp. 450-468.

Wang, C., Pan, R., Wan, X., Tan, Y., Xu, L., Ho, C. S., and Ho, R. C. (2020), "Immediate psychological responses and associated factors during the initial stage of the 2019 coronavirus disease (COVID-19) epidemic among the general population in China", International Journal of Environmental Research and Public Health, Vol. 17 No. 5, pp. 1729-1754.

Wang, Y., Xu, B., Zhao, G., Cao, R., He, X., and Fu, S. (2011), "Is quarantine related to immediate negative psychological consequences during the 2009 H1N1 epidemic?", General Hospital Psychiatry, Vol. 33 No. 1, pp. 75-77.

Wellman, B., and Tindall, D. (1993), "Reach out and touch some bodies: How telephone networks connect social networks", Progress in Communication Science, Vol. 12, pp. 6394.

Westland, J. C. (2010), "Lower bounds on sample size in structural equation modeling”, Electronic Commerce Research and Applications, Vol. 9 No. 6, pp. 476-487.

Whelan, E., Islam, A. K. M. N., and Brooks, S. (2020), "Is boredom proneness related to social media overload and fatigue? A stress-strain-outcome approach", InternetResearch.Vol. 30 No. 3, pp. 869-887.

Wilder-Smith, A., and Freedman, D. O. (2020), "Isolation, quarantine, social distancing and community containment: pivotal role for old-style public health measures in the novel coronavirus (2019-nCoV) outbreak", Journal of Travel Medicine, Vol. 27 No. 2, doi: https://doi.org/10.1093/jtm/taaa020

Williams, L., Rasmussen, S., Kleczkowski, A., Maharaj, S., and Cairns, N. (2015), "Protection motivation theory and social distancing behavior in response to a simulated infectious disease epidemic", Psychology, Health \& Medicine, Vol. 20 No.7, pp. 832837.

Wilson, R. E., Gosling, S. D., and Graham, L. T. (2012), "A review of Facebook research in the social sciences", Perspectives on Psychological Science, Vol. 7 No. 3, pp.203-220. 
Wright, K. B. (2000), "The communication of social support within an on-line community for older adults: A qualitative analysis of the Senior Net community", Qualitative Research Reports in Communication, Vol. 1 No.2, pp. 33-43.

Wu, P., Fang, Y., Guan, Z., Fan, B., Kong, J., Yao, Z., and Hoven, C. W. (2009), “The psychological impact of the SARS epidemic on hospital employees in China: exposure, risk perception, and altruistic acceptance of risk", The Canadian Journal of Psychiatry, Vol. 54 No. 5, pp. 302-311.

Yogeeswaran, K., and Dasgupta, N. (2014), "The devil is in the details: Abstract versus concrete construal of multiculturalism differentially impact intergroup relations", Journal of Personality and Social Psychology, Vol. 106 No. 5, pp. 772-789.

Yoo, E., Rand, W., Eftekhar, M., and Rabinovich, E. (2016), “Evaluating information diffusion speed and its determinants in social media networks during humanitarian crises", Journal of Operations Management, Vol. 45, pp. 123-133.

Zaphiris, P., and Sarwar, R. (2006), "Trends, similarities and differences in the usage of teen and senior public online newsgroups", ACM Transactions on Computer-Human Interaction (TOCHI), Vol. 13 No. 3, pp. 403-422.

Zhang, M. W., Ho, C. S., Fang, P., Lu, Y., and Ho, R. C. (2014), "Usage of social media and smartphone application in assessment of physical and psychological well-being of individuals in times of a major air pollution crisis", JMIRmHealth and uHealth, Vol. 2 No.1, pp. 16.

Zhang, R., and Smith, L. (2019), "Bonding and dissonance: Rethinking the Interrelations Among Stakeholders in Heritage Tourism", Tourism Management, Vol.74, pp.212-223.

Zhou, B., Lu, X., and Holme, P. (2020), "Universal evolution patterns of degree assortativity in social networks", Social Networks, Vol. 63, pp. 47-55.

Zimbardo, P. G. (1999), "Discontinuity Theory: Cognitive and Social Searches for Rationality and Normality-May Lead to Madness", In M. P. Zanna (Ed.) Vol. 31, pp. 345-486. Academic Press. https://doi.org/https://doi.org/10.1016/S0065-2601(08) 602762 


\begin{tabular}{|c|c|c|c|c|}
\hline $\begin{array}{c}\text { Construct } \\
\text { (Latent variables) }\end{array}$ & & Constructs and Definition & Source & $\begin{array}{c}\text { AVE } \\
\text { (SQR of } \\
\text { Average } \\
\text { Variance } \\
\text { Extracte } \\
\text { d) }\end{array}$ \\
\hline $\begin{array}{l}\text { First Order } \\
\text { Latent Variable: } \\
\text { LONELINESS }\end{array}$ & \multicolumn{2}{|c|}{$\begin{array}{l}\text { Loneliness is defined as the distressing condition that an } \\
\text { individual experience subjected to reduced quantity or quality } \\
\text { of social relationships. }\end{array}$} & \multirow{5}{*}{$\begin{array}{l}\text { Russell et al., } \\
\quad \text { (1978) } \\
\text { Hughes et al. } \\
\quad \text { (2004) }\end{array}$} & \multirow{5}{*}{0.935} \\
\hline \multirow{4}{*}{ Measuring Items } & L1 & $\begin{array}{l}\text { These social distancing/lockdown days make me feel } \\
\text { that I lack companionship. }\end{array}$ & & \\
\hline & L2 & $\begin{array}{l}\text { These social distancing/lockdown days often make me } \\
\text { feel alone. }\end{array}$ & & \\
\hline & L3 & $\begin{array}{l}\text { These social distancing/lockdown days make me feel } \\
\text { isolated from others. }\end{array}$ & & \\
\hline & L4 & $\begin{array}{l}\text { These social distancing/lockdown days makes me feel } \\
\text { I don't have people around, whom I can talk to. }\end{array}$ & & \\
\hline $\begin{array}{c}\text { First Order } \\
\text { Latent Variable } \\
\text { Cabin_Fever_Syn } \\
\text { drome(C_F_S }) \\
\end{array}$ & \multicolumn{2}{|c|}{$\begin{array}{l}\text { Cabin fever syndrome is defined as the stressful bad temper } \\
\text { combined with claustrophobic restlessness when an } \\
\text { individual is caught at an isolated place or in a confined } \\
\text { location for a long time. }\end{array}$} & \multirow{6}{*}{$\begin{array}{l}\text { Fritscher (2020) } \\
\text { Robinson (2020) }\end{array}$} & \multirow{6}{*}{0.756} \\
\hline \multirow{5}{*}{ Measuring Items } & CFS1 & I feel restless staying at home. & & \\
\hline & CFS2 & $\begin{array}{l}\text { I have trouble concentrating while staying at home } \\
\text { during social distancing/lockdown. }\end{array}$ & & \\
\hline & CFS3 & $\begin{array}{l}\text { I have food cravings while staying at home during } \\
\text { social distancing/lockdown. }\end{array}$ & & \\
\hline & CFS4 & $\begin{array}{l}\text { I have a feeling of social isolation while staying at } \\
\text { home during social distancing/lockdown. }\end{array}$ & & \\
\hline & CFS5 & $\begin{array}{l}\text { I feel lethargic while staying at home during social } \\
\text { distancing/lockdown. }\end{array}$ & & \\
\hline $\begin{array}{l}\text { First Order } \\
\text { Latent Variable } \\
\text { COVID-19 Fear }\end{array}$ & \multicolumn{2}{|c|}{$\begin{array}{l}\text { Fear of individuals during the COVID-19 outbreak, to get } \\
\text { infected by the coronavirus, which is marked by various fear- } \\
\text { related symptoms. }\end{array}$} & \multirow{5}{*}{$\begin{array}{l}\text { De Zwart et al. } \\
\quad \text { (2007) } \\
\begin{array}{c}\text { McAlonan et al. } \\
\quad(2007)\end{array} \\
\text { Wang et al. } \\
\quad(2020) \\
\text { Zhang et al. } \\
\quad(2014)\end{array}$} & \multirow{5}{*}{0.964} \\
\hline \multirow{4}{*}{ Measuring Items } & $\begin{array}{l}\text { COVI } \\
\text { D1 }\end{array}$ & $\begin{array}{l}\text { Even in social distancing/lockdown, I am often } \\
\text { worried about being at the risk of the coronavirus. }\end{array}$ & & \\
\hline & $\begin{array}{l}\text { COVI } \\
\text { D2 }\end{array}$ & $\begin{array}{l}\text { Even in social distancing/lockdown, I feel extremely } \\
\text { anxious when I think of an individual and his family } \\
\text { problems after a possible risk of the incidence of } \\
\text { coronavirus. }\end{array}$ & & \\
\hline & $\begin{array}{l}\text { COVI } \\
\text { D3 }\end{array}$ & $\begin{array}{l}\text { Even in social distancing/lockdown, I get anxious and } \\
\text { disappointed when I think of being affected by a } \\
\text { coronavirus. }\end{array}$ & & \\
\hline & $\begin{array}{l}\text { COVI } \\
\text { D4 }\end{array}$ & $\begin{array}{l}\text { Even in social distancing/lockdown, I am living with } \\
\text { the fear of infection. }\end{array}$ & & \\
\hline $\begin{array}{c}\text { First Order } \\
\text { Latent Variable } \\
\text { Traumatic Stress } \\
\quad\left(\mathbf{T}_{-} \text {S) }\right.\end{array}$ & \multicolumn{2}{|c|}{$\begin{array}{l}\text { Traumatic stress is defined as the stress experienced by } \\
\text { individuals during COVID } 19 \text { outbreak, characterized by fear } \\
\text { and anxiety about COVID } 19 \text { infection; this can be } \\
\text { overwhelming and trigger strong negative emotions in } \\
\text { individuals. }\end{array}$} & \multirow{6}{*}{$\begin{array}{l}\text { Huang et al. } \\
\qquad(2020) \\
\text { Holshue } \text { et al. } \\
\quad(2020)\end{array}$} & \multirow{6}{*}{0.880} \\
\hline \multirow{5}{*}{ Measuring Items } & TS1 & $\begin{array}{l}\text { The coronavirus outbreak gave me difficulties staying } \\
\text { asleep. }\end{array}$ & & \\
\hline & TS2 & $\begin{array}{l}\text { I think about the coronavirus, even when I didn't } \\
\text { mean to. }\end{array}$ & & \\
\hline & TS3 & I have waves of strong feelings about the coronavirus. & & \\
\hline & TS4 & $\begin{array}{l}\text { I had dreams about coronavirus affecting me and my } \\
\text { family. }\end{array}$ & & \\
\hline & TS5 & I am watchful and on-guard about coronavirus. & & \\
\hline $\begin{array}{l}\text { Second-Order } \\
\text { Latent Variable }\end{array}$ & \multicolumn{2}{|c|}{ Psychological impact refers to the effect caused by COVID 19} & $\begin{array}{l}\text { Wang et al. } \\
\text { (2020) }\end{array}$ & 0.953 \\
\hline
\end{tabular}




\begin{tabular}{|c|c|c|c|c|}
\hline $\begin{array}{l}\text { Psychological } \\
\text { Impact(P I) }\end{array}$ & \multicolumn{2}{|c|}{ pandemic on an individual's psychological health. } & \multirow{5}{*}{ Cao et al. (2020) } & \\
\hline \multirow{4}{*}{$\begin{array}{l}\text { Measuring } \\
\text { Variables }\end{array}$} & \multicolumn{2}{|r|}{ LONELINESS } & & \\
\hline & \multirow{2}{*}{\multicolumn{2}{|c|}{$\frac{\text { Cabin Fever Syndrome (C_F_S) }}{\text { Covid_19_Fear }}$}} & & \\
\hline & & & & \\
\hline & \multicolumn{2}{|c|}{ Traumatic Stress } & & \\
\hline $\begin{array}{l}\text { First Order } \\
\text { Latent Variable: } \\
\text { Social Distancing } \\
\text { Attitude (S_D_A) }\end{array}$ & \multicolumn{2}{|c|}{$\begin{array}{l}\text { Social distancing attitude refers to the attitude individuals } \\
\text { hold with respect to accepting social distancing among } \\
\text { people, as a means to prevent the spread of coronavirus } \\
\text { infection. }\end{array}$} & \multirow{4}{*}{ 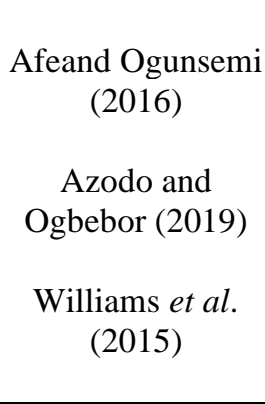 } & \multirow{4}{*}{0.968} \\
\hline \multirow{3}{*}{ Measuring Items } & AT1 & $\begin{array}{l}\text { In my opinion, the use of social distancing will have a } \\
\text { positive impact to control COVID-19 }\end{array}$ & & \\
\hline & AT2 & $\begin{array}{l}\text { The use of social distancing is beneficial for the care } \\
\text { of the patients }\end{array}$ & & \\
\hline & AT3 & $\begin{array}{l}\text { I find it interesting to use social distancing for the } \\
\text { control of COVID-19 }\end{array}$ & & \\
\hline $\begin{array}{c}\text { First Order } \\
\text { Latent Variable } \\
\text { Social Distancing } \\
\text { Intention (S_D_I) } \\
\end{array}$ & \multicolumn{2}{|c|}{$\begin{array}{l}\text { Social distancing intention refers to the intention to adopt } \\
\text { social distancing among people, as a means to prevent the } \\
\text { spread of coronavirus infection. }\end{array}$} & \multirow{4}{*}{$\begin{array}{l}\text { Williams et al. } \\
\quad(2015) \\
\text { Fong et al. }(2020)\end{array}$} & \multirow{4}{*}{0.971} \\
\hline \multirow{3}{*}{ Measuring Items } & IN1 & $\begin{array}{l}\text { I have the intention to use social distancing when it } \\
\text { becomes useful to avoid COVID-19 }\end{array}$ & & \\
\hline & IN2 & $\begin{array}{l}\text { I have the intention to use social distancing when } \\
\text { necessary to provide good results to avoid COVID }-19\end{array}$ & & \\
\hline & IN3 & $\begin{array}{l}\text { I have the intention to use social distancing for the } \\
\text { care of myself and others }\end{array}$ & & \\
\hline $\begin{array}{c}\text { Second-Order } \\
\text { Latent Variable } \\
\text { Cognitive } \\
\text { Appraisal of } \\
\text { Voluntary } \\
\text { Social Distancing } \\
\text { Compliance } \\
\text { (CAVSD) } \\
\end{array}$ & \multicolumn{2}{|c|}{$\begin{array}{l}\text { Cognitive appraisal refers to the personal interpretation of the } \\
\text { seriousness of the COVID } 19 \text { pandemic that impacts whether } \\
\text { the pandemic is perceived as stressful. }\end{array}$} & \multirow[t]{3}{*}{$\begin{array}{l}\text { Gurnani (2020, } \\
\quad \text { March 17) }\end{array}$} & \multirow[t]{3}{*}{0.812} \\
\hline \multirow{2}{*}{ Measuring Items } & \multicolumn{2}{|r|}{ Social Distancing Attitude } & & \\
\hline & & Social Distancing Intention & & \\
\hline $\begin{array}{c}\text { First Order } \\
\text { Latent Variable } \\
\text { Social Networking } \\
\text { Usage } \\
\text { Intensity }\left(\mathbf{S}_{-} N\right) \\
\end{array}$ & \multicolumn{2}{|c|}{$\begin{array}{l}\text { Social networking intensity is defined as the extent to which as } \\
\text { an individual is actively occupied in social } \\
\text { networking activities }\end{array}$} & \multirow{5}{*}{$\begin{array}{l}\text { Adapted from, } \\
\text { Eidand Al-Jabri; } \\
\quad(2016)\end{array}$} & \multirow{5}{*}{0.870} \\
\hline \multirow{4}{*}{ Measuring Items } & SNI1 & $\begin{array}{l}\text { During social distancing/lockdown I am using social } \\
\text { networking (SN) more than normal. }\end{array}$ & & \\
\hline & SNI2 & $\begin{array}{l}\text { During social distancing/lockdown I am logging into } \\
\text { my SN sites more frequently. }\end{array}$ & & \\
\hline & SNI3 & $\begin{array}{l}\text { During social distancing/lockdown I am } \\
\text { sending/forwarding messages to my friends more than } \\
\text { normal. }\end{array}$ & & \\
\hline & SNI4 & $\begin{array}{l}\text { During social distancing/lockdown I am using social } \\
\text { networking sites for reading news. Attending social } \\
\text { gathering. }\end{array}$ & & \\
\hline
\end{tabular}

